\title{
Günümüzde Kadının Boşanma Deneyimleri: Akademisyen Kadınlar Üzerine Bir Araştırma
}

\author{
The Divorce-Related experiences of Women in Contemporary Society: \\ A Study of the Female Academician
}

\section{Sinem Burcu UĞUR*}

Öz: Modernleşme çabası içinde olan günümüz toplumlarında hızlı bir değişime tanıklık edilmektedir. Yaşanan değişim ve dönüşümlerden toplum dinamiği içerisinde biçimlenmesi bakımından aile kurumu da payını alır. Ailenin birliğinin ve devamlılığının sağlanmasına yönelik baskı, bireysel istek ve arzuların daha görünür hale geldiği günümüz evliliklerinde görece azalır. Aksine günümüz toplumları, evliliğin çıkmaza girdiği zamanlarda bireylere bu çıkmazdan kurtulmalarını sağlayacak farklı yollar sunar. Boşanma da bu yollardan bir tanesidir. Eşlerin karşılıklı istek ve arzularının uyuşmamasının kolaylıkla bir boşanma nedeni olabildiği günümüz toplumlarında bireyselleşmenin yanı sıra yasal düzenlemeler, ahlaki ve kültürel değerlerin değişmesi, evlilik birliğinin korunması yönündeki dini inanışların çözülmeye uğraması ve boşanmanın artan toplumsal kabulü; bireyler için boşanmanın önünü açarken, boşanma oranlarını da dünya çapında yükseltir. Bu makalede toplumsal değişme sürecinde aile ve evlilik kurumunun işleyişi ve boşanma olgusunun ortaya çıkışı, gelişimi ve sonuçları tartışılmıştır. Çalışmada kullanılan veriler Akdeniz Üniversitesi'nde çalışan boşanmış akademisyen kadınlarla yapılan derinlemesine görüşmelerden elde edilmiş̧ir. Boşanmış akademisyen kadınların evlilik ve boşanma süreçlerine ilişkin veriler toplanarak boşanmalarının ardında yatan nedenler belirlenmiş, ayrıca boşanmaların söz konusu kadınların yaşamlarına nasıl etkide bulunduğu ve boşanma sonrası sürece adaptasyonları incelenmiştir.

Anahtar sözcükler: Antalya, aile, evlilik, boşanma deneyimleri, kadın, akademisyen kadınlar

Abstract: A rapid transformation can be seen in today's societies engaged in the struggle termed modernization. The institution of the family receives its share, in terms of its re-shaping due to the changes and transformations of social dynamics. The social pressures are no longer applied in order to ensure family unity and continuity - these no longer exist in today's marriages, which are dominated by individualised wishes and desires. On the contrary, today's societies offer married individuals a multiplicity of options to cut and run when they reach crisis point, with divorce being one of these options. In today's societies the conflicting desires and wishes of spouses can easily lead to divorce. In addition to this, legal reforms, changes in moral and cultural values, disassociation from religious beliefs that imposed protection of the matrimonial bond and the increasing acceptance of divorce, as well as increasing individualization, opened the door to, and have increased, divorce rates across the world. This study explains the functioning of marriage and family institution and the formation, development and shift in the phenomenon of divorce within the course of social change. The data related to the marriage and divorce processes employed in this study were obtained through in-depth interviews conducted with divorced female academicians at Akdeniz University, Antalya. The articulated causes of a divorce and how this affects the life of a female academician and her adaptation to the post-divorce period were analysed.

Keywords: Antalya, family, marriage, divorce-related experiences, woman, female academician

\footnotetext{
* Doktora Öğrencisi, Akdeniz Üniversitesi, Sosyal Bilimler Enst., Sosyoloji Bölümü, Antalya, ssinembalkan@live.com
} 
Toplumsallaşma sürecinin ilk olarak ortaya çıktığı, kan, cinsel ilişki ya da yasal bağlarla birbirine bağlı insanlardan oluşan, karşılıklı ilişkilerin belli kurallara bağlandığ 1 , o güne dek toplumda oluşturulmuş maddi manevi zenginlikleri kuşaktan kuşağa aktaran, biyolojik, psikolojik, ekonomik, toplumsal, hukuksal vb. yönleri bulunan toplumsal bir kurumu (Sayın, 1990, 2) ifade eden ailenin tanımı zaman içinde pek çok değişiklik gösterir. Aile kavramına ilişkin yeni tanımlamalarda, meydana gelen sosyal değişimlerin aile ve evlilik kurumlarına yansıyarak söz konusu kurumlara hem yapısal hem de işlevsel olarak yeni biçimler kazandırmas1 ana etkiye sahiptir (Clarke-Stewart, \& Brentano, 2006, 29-30).

Evlilik kurumu aracılığıla kurulan aile, modern dönemle birlikte toplumsal yapıda meydana gelen değişmelere paralel bir dönüşüm göstermektedir. Toplumun bir durumdan başka bir duruma geçtiği modernleşme ve modernleşmenin küresel bir düzeyde yaşanmasıyla, aileler yapısal ve biçimsel olduğu kadar, aile içi ilişkileri, güç ve iktidarın kullanımı açısından da değişimler yaşamaktadır (Beck, \& Beck-Gernsheim, 2012, 10-11). Ekonomik işlevlerin aile birliğinden soyutlanması evliliğin dışsal işlevlerini azaltırken; onu duygusal doyuma ve anlaşmaya dayanan bir kurum haline dönüştürmekte, evlilik kurumu mutluluğun aracı, duygusal ve cinsel tatmin kaynağı olarak şekil ve anlam değiştirmektedir (Kandiyoti, 1984, 19).

Günümüz evliliklerinin öncelikli amacı, bireysel ihtiyaçların karşılanması, duygusal tatmin ve destektir. Evlilikler için öncelikli motivasyon, bireysel mutluluktur. Bugün evliliklerde evlilik yemini ve çocukların sosyalizasyonu görevinden çok, karşılıklı duyulan aşka vurgu yapılır. Evlilikler görevlere değil, romantik aşka, özgür seçimlere dayanır (Clarke-Stewart, \& Brentano, 2006, 31). Gelenekselleşmiş aile yapısındaki değişim, aile ve evlilik biçimlerindeki çeşitlilikle görünür hale gelir. İçinde yaşanılan yeni firsatlarla dolu dünya, aile kalıplarında pek çok değişikliğe tanıklık ederken, dünya üzerindeki tüm toplumlar farklı şiddetlerde ve farklı kültürel bağlamlarda da olsa bu ailesel dönüşümü deneyimler (Giddens, 2005, 172-173).

Günümüz toplumlarının deneyimledikleri ailesel dönüşümlerden biri, özellikle Batı toplumlarında yaygın olan tek ebeveynli ailelerdir. $\mathrm{Bu}$ aile tipi, eşlerden birinin ölümüyle ortaya çıkabildiği gibi, günümüz toplumlarında tek ebeveynli aileler daha çok boşanmalardaki artışın bir sonucu olarak görünür ya da basitçe evliliğe olan isteksizlikten kaynaklanır (Browne, 2005, 228). Pek çok toplum bilimci tek ebeveynli aile sayısındaki bu artışı, yüksek boşanma oranlarına bağlar ve tek ebeveynli ailelerin ortaya çıkış nedeni olarak kısaca toplumlarda boşanmanın hızla artış göstermesi ve bireylerin evliliğin getirdiği sorumluluklardan uzaklaşma isteğini gösterir (Canatan, \& Yıldırım, 2009, 98).

Boşanma, aile birliğini sona erdiren önemli bir karar ve toplumsal bir olgudur. Boşanma olgusu, yasalar çerçevesinde yapılmış olan bir evliliğin eşlerin yeni bir evlilik yapabilecekleri şekilde hukuki bir kararla, yine yasal olarak tamamen sona erdirilmesi olarak tanımlanır (Boşanma Nedenleri Araştırması, 2009, 1). Hukuken eşler hayattayken evlilik ilişkisinin mahkeme kararı ile sonlandırılmasını ifade eden boşanma, sosyolojik açıdan kadın ve erkek arasında yasal, duygusal ve cinsel bağların bitirilmesi kararını içerir. Boşanma olgusu psikolojik boyutuyla ele alındığında ise, boşanmanın, aile birliğinin bozulmasına, ailenin bölünmesine ya da bütünüyle dağılmasına yol açarak, bireylerin yakın çevrelerini de kapsayacak bir biçimde bütün aile üyelerini sarsan karmaşık bir olgu olduğu görülür (Arpac1, \& Tokyürek, 2012, 2).

Nedenleri, sonuç ve etkileri toplumdan topluma, zamandan zamana ve kişiden kişiye değişiklik gösteren boşanma olgusu, aile ve evlilik kadar eskidir. Son yıllarda boşanma oranlarında görülen artış ve boşanmaya yönelik tutumlardaki farklılıklar, Türkiye için de boşanmaları ciddi bir sosyal sorun haline getirmektedir. Boşanmaların önemli ölçüde artması, evliliklerin sona ermesine neden olan değişkenlerin belirlenmesini ve boşanma sonrasında ailede değişen rolleri 
anlamay1 gerektirmektedir.

Boşanmanın neden olduğu sorunlar ve getirdiği sorumluluklar, bireyler için zor bir süreci başlatırken; özellikle boşanmış kadınlar yalnız yaşamanın yanı sıra tek ebeveyn olarak gerek sosyal yaşamlarında gerekse de çalışma yaşamlarında bu durumdan erkeklere oranla daha fazla etkilenmektedirler (Parrillo, Stimson, \& Stimson, 1996, 297). Bu bağlamda, boşanma oranlar1nın en yüksek olduğu illerden birisi olan Antalya'da kadınların boşanma neden ve sonuçlarının araştırılması önem taşımaktadır.

\section{a) Kadınlarda Boşanmanın Ortaya Çıkış Dinamikleri}

Bugün dünyanın hemen her yerinde yasalar, boşanmak isteyen bireyler için evliliklerini sona erdirebilmelerine olanak sağlayan daha fazla gerekçe sunmaktadır. Boşanmaları daha kolay hale getiren bu durum boşanma oranlarını da dünya çapında yükseltmektedir. Bireylerin günümüz toplumlarında neden daha fazla boşanma talebinde bulundukları ise, sosyo-psikolojik, ekonomik ve sosyolojik olarak birbiriyle bağlantılı pek çok değişkenle açıklanabilmektedir.

Yüksek boşanma oranlarında etkili olan değişkenlerden en önemlisi kadınların çalışma hayatına katılımlarıdır. Üretim ve istihdam politikaları, ekonomik krizler, nüfus artış hızı, kentleşme, toplumun insan kaynağının yetiştirilmesine verdiği önem gibi kaynaklarca işgücü arzı artan (Minibaş, 1998, 335) kadınların iş hayatında yer almaları onların tamamen kendilerine ait yeni bir alana sahip olmalarını sağlarken; sahip oldukları iş, bu alanda yaşayabilmeleri için gerekli geliri de onlara sunar (Coates, 2008, 37-38). Kadınların ücretli olarak çalışması, ekonomik özgürlük anlamı taşıması bakımından aile içindeki ve toplumdaki rollerini değiştirir (Koray, 1993, 27). Özellikle eğitim düzeyinin yüksek olduğu gruplarda iş gücüne katılım, toplumsal cinsiyet rolleri bağlamında geleneksel ev kadını, eş ve annelik rollerinin yanı sıra iş hayatında da roller üstlenmeleri anlamına gelir ve kadının zaten ev içinde fazlaca olan görevlerine dışarıda da yenilerinin eklenmesini ifade eder (İmamoğlu, 1993; Telsiz, 1995). Bununla birlikte çalışma hayatına katılarak ailenin gelirini sağlama sorumluluğunu eşleriyle paylaşan kadınların aksine, erkekler günümüz çalışan kadınlarının artan görevlerini onlarla paylaşma eğiliminde değillerdir (Aydın, \& Baran, 2010, 117-118). Kadınların işgücüne katılmaları ve özellikle de yüksek statü getiren işlerde yer almaları çoğu zaman olumlu bir gelişme olarak değerlendirilmesine rağmen, kadının ekonomik olarak özgürleşmesine olanak sağlayan bu durum gerçekte kadınların aile yaşamlarını olumsuz etkileyebilir. Aile içindeki rolleri ile çalışma yaşamındaki rollerini aynı ölçüde yerine getirme zorunluluğu bir yandan kadınların kendilerini bu roller arasında sıkışmış hissetmelerine neden olduğu gibi öte yandan çalışma hayatının kadının taleplerini artırması ise kadının evliliğini sorgulamasına neden olabilmektedir (İmamoğlu, 1993; Telsiz, 1995; Aydın, \& Baran, 2010).

Kadınların ekonomik olarak bağımsızlık elde etmeleri, onların kötü giden evliliklerini bitirme olasılıklarını artırmakla birlikte, bu demek değildir ki ekonomik durumu iyileşen her kadın boşanma eğilimindedir. Evliliklerinde kadın ve erkeğin birbirini tamamlayan şekilde konumlanıp, ev içi görevlerinde bir iş bölümüne gitmeleri; evliliğin birliğini destekler. Bu durum ise ekonomik bağımsızlık idealinin temelini oluşturur. Ekonomik bağımsızlık idealine göre, eşlerin aile içi rollerinde ve görevlerindeki benzerlik ancak kadının da iş hayatına katılımıyla sağlanır. Bu durum ise çiftlere ortak değerler kazandırarak, onların birbirlerinin hislerini paylaşmalarına firsat verir. Evliliklerinin daha fazla anlayış ve paylaşma ortamı içinde gerçekleşmesine olanak sağlayarak, eşlerin ilişkilerini de geliştirir (Clarke-Stewart, \& Brentano, 2006, 33). Toplumun genelinde meydana gelen değişimler, kadınların iş gücü arzlarını artırarak iş hayatında yer almalarına olanak sunduğu gibi kişisel beklentilerde de bir değişim yaratarak 
boşanma oranlarındaki artışta etkin bir rol oynarlar.

Bundan birkaç on yıl önce en kutsal değer olarak kabul edilen aile ve aile hayatının aksine gençler bireysel yaşam tarzına yönelme eğilimi içerisindedirler. Son yıllarda özellikle genç kuşaklar arasında giderek rağbet gören bireysel yaşam, topluluk yaşamının yerini almaktadır. Birey merkezli yaşam tarzının bu denli üstün tutulmasında ise özel yaşama atfedilen değerlerin büyümesi, kişinin kendini keşfi etkili olur (Süleymanov, 2009, 13). Artan bireycilik eğilimiyle aile, evlilik içindeki bireylerin kişisel bağımsızlık ve haklarına daha fazla önem veren bir kurum halini alır ve karşılıklı işbirliğine dayalı iletişim, giderek artan ölçüde bu yeni aile modellerinde görünür olur (Kandiyoti, 1984, 19). Duygusal etkileşimin anne, baba ve çocuk arasında merkez konumda olduğu bu ailesel dönüşümde (Giddens, 2005, 172-173) evlilik, giderek cinselliğin yönlendirdiği, karşılıklı sevgiye dayalı tercihlerin ön plana çıktığı bir birliktelik olarak yaşanmaya başlar (Beck, \& Beck-Gernsheim, 2012, 10-12). Evliliklerin artık her iki birey için de psiko-sosyal doyumun her an yaşatılabildiği, karşılıklı olarak romantik sevgi, dostluk ve sırdaşlık temeline dayalı olması ve uyum içinde sürdürülmesi beklenir (Aydın, \& Baran, 2010, 118-120). Birlikteyken nitelikli zaman geçirilmesinin ötesinde, birlikte harcanan zamanın her iki taraf için de ifade ettiği anlamın yükselmesi beklentisi günümüz toplumlarının ayırt edici bir özelliğidir (Parrillo, Stimson, \& Stimson, 1995, 293). Ancak bireylerin seçim özgürlüklerinin yüceltildiği günümüz toplumlarında, bu özgürlüklerin evlilik ilişkisi içerisindeki bireyler için yeni birer gerilim kaynağı olabileceğini söylemek yanlış olmaz.

Evlilik yoluyla kurulan birlikteliğin aktif bir öznesi olduğunun farkına varan kadın evlilik yaşantısına ilişkin olarak daha fazla beklenti içine girer ve taleplerini daha fazla dile getirir (Alptekin, 2011, 46). Erkeklerin yanı sıra, artan oranda çalışma hayatında yer alan kadın için, günümüzde mesleki olduğu kadar kişisel gelişim de önem kazanır. Fakat bir kariyer hedefi olan ve meslek yaşamında ilerleme kaygısı güden kadının konumu, günümüz aileleri için yeni tartışma alanları yaratır. Sevgi, cinsellik, çocuklar ve ev içi ilişkilerin tartışma konusu olduğu ailelerin kadının iş yaşamına girmesiyle tartışma alanları da artar. Çiftler artık iş yaşamı, ekonomi, siyaset, eşitsizlikler ve meslek hayatı gibi konular üzerinde de tartışırlar (Beck, \& Beck-Gernsheim, 2012, 10-12). Toplumun üyelerinin anlam ve kişisel tatmin arayışına girdiği bu değişimin bir sonucu olarak, içinde bulunduğumuz yıllar mutsuz giden evlilikleri karşısında bireylerin daha az tolerans göstermeye başladıkları yıllardır (Clarke-Stewart, \& Brentano, 2006, 9-10).

Yüksek boşanma oranlarına ilişkin tüm bu faktörler ele alındığında, boşanma oranlarındaki artışta en büyük etki sahibinin kadının rollerindeki değişim olduğu görülmektedir. Kadın haklarının gelişmesi, eğitim seviyesinin yükselmesi ve toplumsal yaşama katılımı gibi değişmeler ailenin yaşam düzeyini yükseltirken, artan boşanma oranlarına da bir açıklık getirmektedir.

Daha önceleri görevleri evle sınırlı kalan kadının, günümüz toplumlarında değişen toplum yapısıyla bağlantılı olarak erkeğin yanı sıra ev dışında ücret karşılığı çalışmaya başlaması, geleneksel cinsiyet rollerinden tamamen sıyrıldığı anlamına gelmez. Gerçekte cinsiyete dayalı iş bölümü çerçevesinde "ekmek kazanan" erkek ve ailedeki bireylerin bakımlarını sağlayan "dişi kuş" kadın rolü ortadan kalkmaz (Adak, 2007, 139). Geleneksel yaşama özgü erkek egemen kültür, modern yaşamda gerçekleşen toplumsal değişme sürecinde daha yavaş bir değişim geçirirken bu durum ev içi iş bölümünün istenilen oranda eşitlikçi hale gelmesine engel olarak kadınların iş yükünü artırmaktadır (Aydın, \& Baran, 2010, 117-118). Nitekim kadınların iş gücüne katılımları, hem aile içindeki hem de çalışma yaşamındaki rollerini aynı ölçüde yerine getirme zorunluluğunu doğururken, bunun aksine erkeklerin ara sıra yapılabilen ve işin yapılma zamanıyla ilgili kişisel karar verme olanaklarına sahip oldukları işlerle uğraşmaları (Telsiz, 1995, 83-84) kadınların rol çatışması yaşamalarına neden olur. Öte yandan ekonomik olarak 
güvence elde etmelerine olanak sağlayan çalışma hayatının kadının taleplerini artırması ise kadınların evliliğini sorgulamasına neden olabilmektedir. Hayatını idame ettirebilmek için eşine muhtaç olmayan kadınlar mutsuz oldukları bir evliliği sürdürmek konusunda daha az isteklidir.

\section{b) Kadınlarda Boşanma Sonrası Yaşam}

Boşanmanın ortaya çıkış dinamikleri boşanma sonrası yaşam üzerinde de etkilere sahiptir. Boşanma, kaçınılmaz olarak hem kadın hem de erkeklerin ekonomik durumları üzerine etki ederek olumsuzluklar yaratır. Ancak boşanmanın ardından hayat standartlarında büyük bir düşüş gerçekleşen bireyler arasında kadınların sayısı çok daha fazladır ki, bu sayı boşanmış her dört kadından üçünü ifade etmektedir (Coates, 2008, 73).

Evliliği süresince ev dışında bir iş yaşantısı olmayan ya da geçici işlerde çalışan kadınlar, düzenli bir iş yaşantısı olan kadınlara oranla boşanmalardan daha fazla etkilenerek daha dezavantajlı hale gelirler. Evlilik süresince ücretli bir işte çalışmayan ve boşanmanın ardından öncelikli hedefleri kendilerine bir yaşam sağlayabilmek, geçinebilmek olan bu kadınların boşanma sonrasında yapılan mal paylaşımında kendilerine çok az mal düşmesi, ekonomik kırılganlıklarını artıran kaynaklardandır (Newman, 2009, 394). Kadınların boşanma sonrası daha dezavantajlı durumda olmasının ardındaki temel nedenlerden bir diğeri de biten evliliklerde çoğunlukla çocukların da yer alması ve kadınların eşlerine oranla çoğunlukla kendilerini çocuklarına adayan taraf olmalarıdır (Fine, Ganong, \& Demo, 2005, 234). Çocukların eğitim ihtiyaçları, boş zaman faaliyetleri, büyüdükçe artan ihtiyaçlar gibi konular, tek başına çocuk yetiştiren annelerin çocuklarına ilişkin ekonomik kaygılarını oluşturur (Tek Ebeveynli Aileler, 2011, 121-124). Özellikle küçük çocuk annelerinin çocuklarının bakımına daha fazla zaman ayırmasının gerekliliği, anneleri çoğunlukla iş hayatlarını sonlandırmak zorunda bırakarak, onların ekonomik dezavantajlı konumlarını pekiştirir (Fine, Ganong, \& Demo, 2005, 234). Gerek aile içinde gerekse de dışında kadınlara sunulan roller, boşanmanın ardından tek başlarına ya da çocuklarıyla birlikte bir yaşam sürdürebilecekleri zemini hazırlamaktan uzak olmakla birlikte, boşanmanın yarattığı farklı sorunlar kadınların çalışma hayatına katılmalarının da önünü açabilmektedir.

Boşanma deneyimine sahip kadınlar boşanma güçlüklerine cevaben, kendilerini uzun soluklu ekonomik bunalımdan koruyacak olan bir iş arama eğilimindedirler. Bu bakımdan da söz konusu boşanmış kadınların ilk evliliklerini sürdüren kadınlara kıyasla herhangi bir işte istihdam edilmeleri daha yüksek olasılıklıdır. Ayrıca boşanmış kadınlar yeniden evlilik gerçekleştirseler de çoğunlukla çalışma hayatına devam ederler. Bu durum, işe alınmanın kadınlar arasında boşanmayı takip eden uzun soluklu bir örüntü olarak da ortaya çıkabileceğine işaret etmektedir (Forste, \& Heaton, 2004, 111).

Evlilikleri boyunca aktif olarak çalışma hayatında bulunma ise bir taraf olarak kadınların boşanma sürecinde daha güçlü olmalarını sağlamaktadır. Nitekim yapılan çalışmalar (Krishnan, 1994) çalışma deneyimine sahip kadınların, çalışmayan ya da almış oldukları eğitimle çalışma yaşamında yer alma yeterliliğine sahip olmayan hemcinsleriyle kıyaslandıklarında evlilik birliğinin bozulmasında daha güçlü bir davranış sergilediklerini ortaya koymaktadır. Evlilik öncesinde çalışma deneyimi olan kadınlar boşanma kararının alınması sürecinde daha güçlü olabildikleri gibi, daha sonraki süreçte de çalışma yaşamındaki etkinlikleri devam edebilmektedir. Üstelik evlilikleri boyunca çalışıyor konumda bulunan söz konusu kadınların, evlilik öncesi ve evlilik sürecinde benzer deneyim ve etkinliğe sahip olmayan kadınlara kıyasla, örgütlü ve mesleki formasyon gerektiren işlerde çalışma olasılıkları daha yüksektir (Demircioğlu, 2000, 143144). Bu durum ise, boşanma sonrası ailenin geçimini sağlayarak, aile reisi konumunu üstlenen 
kadının boşanmanın yarattı̆̆ ekonomik bunalımdan toparlanma sürecinde oldukça etkili olmaktadir.

Boşanma sonrası periyodun en keskin görünüşü evlilik süreci ve evlilik öncesindeki arkadaşlar ve aileyle ilişkilerin yeniden tanımlanıp, yapılanmasıdır. Boşanma sürecinde aileler önemli bir rol oynarlar. Boşanma eğiliminde olan çiftlerin aileleri özellikle çocuğu da kapsayan evliliklerin devam ettirilmesi yönünde bir tutum sergiler (Coates, 2008, 199-200) ve genelde boşanmış kızlarını kabul etmek istemezler. Kadınların boşandıktan sonra soy aileleri tarafından kabul görmemelerinin nedeni temelde aile statüsünün azalmasından duyulan kaygıdır. Toplumun boşanmaya karşı gösterdiği direnç ve özellikle de boşanmış kadına karşı tutumlar, boşanmayı kadının başarısızlığı gibi gören anlayış, ailelerin boşanmayı hoş karşılamamasında etkili olur (Özar, \& Yakut-Çakar, 2012, 4). Bunun yanı sıra boşanmış kadının ekonomik bir yük olarak algılanması ve yeniden evlenme olasılığının düşüklüğü ailelerin boşanmış kızlarının yanında yer alması olasılıklarını azaltır (Sucu, 2007, 59-60). Boşanmaya yönelik sert tutumlara yol açan tüm bu nedenler kadının aile içindeki statüsünü de düşürür. Ne var ki ailenin boşanmaya yönelik baskıcı ve kontrolcü tutumları, kadının eğitim düzeyi ve mesleki statüsüne bağlı olarak farkl11ık göstermektedir. Öğretim üyesi, doktor, avukat gibi profesyonel mesleklere sahip olan kadınların aileleri boşanma söz konusu olduğunda daha destek çıkan ve anlayışlı bir tavır sergilerler. Boşanmaya karşı tutumlar eğitim düzeyi ve mesleki statüye olduğu gibi, sosyal sınıflara göre de farklılaşır. Alt orta sınıf kadınına kıyasla üst orta sınıftaki kadının boşanması daha fazla kabul görür. Bu bakımdan ailenin boşanma karşısındaki geleneksel ve korumacı tavrının azalıp, boşanmanın onaylanabilirliğinde; ailenin sınıfsal konumu, kadının eğitim düzeyi ve mesleki statüsü etkili olmaktadır (Demircioğlu, 2000, 161-162).

Boşanma sonrasında arkadaş çevresinde de bir daralma olur. Evlilik eşler arasında ortak bir sosyal çevrenin oluşturulmasını sağladığı için, boşanma ile birlikte ortak olan bu ilişkiler de değişime uğramaktadır (Demircioğlu, 2000, 169). Ne var ki kadın ve erkekler söz konusu bu değişimi farklı deneyimlemektedirler. Bu farklılıkta belirleyici olansa; kadın ve erkeğin farklı sosyalizasyonlarıdır. Kadının sosyalizasyonu sürecinde evlenme ve aile sahibi olma büyük önem taşır. Kültürel yapı, kadını kendisi için en ahlaklı olan eş ve annelik rollerine yönlendirir (İlbars, 2007, 3-4). Bu rollerini uygun bir biçimde yerine getirebilmeleri için kadınlar psikolojik olarak olgun, duyarlı ve sorumluluk sahibi olmaları beklentisi çerçevesinde bir sosyalizasyon sürecine tabi tutulurlar (İçli, 2007, 335). Ancak sosyo-kültürel yapının kadına yüklemiş olduğu aile içi roller, kadında maddi ve kültürel anlamda erkeğe bağımlılık yaratır (İlbars, 2007, 3-4). Günümüz toplumlarında kadınların artan oranda meslek ve kariyer edinmeleri bu beklentilerde çok değişiklik yaratmamış, özellikle kültürel anlamda kadının erkeğe bağlı pozisyonu pek değişmemiştir (İçli, 2007, 335). Bu bağlılık, evlilik süresince kadının arkadaşlıklarının büyük ölçüde eşin arkadaşları olarak kurulup sürdürülmesinde etkili olmaktadır. Bu bakımdan da eşle oluşturulan sosyal çevre, büyük bir çoğunlukla boşanmanın akabinde kaybedilmektedir.

Boşanmış bireyler çiftlerle kurulan sosyal çevreye uyum sağlayamayacaklarını ya da boşanmalarından ötürü kendi davranışlarının yargılanacağını düşünme, çevrelerindeki çiftlerin mutluluğunu kıskanıp kendini mutsuz hissetme, boşanmayla sonuçlanan evlilikteki sorunların arkadaşlar arasında konuşulmasından kaçınma gibi gerekçelerle eski arkadaşlarıyla ilişkilerini sonlandırma eğilimi gösterirler (Clarke-Stewart, \& Brentano, 2006, 69). Özellikle çocuğun da var olduğu boşanmalarda çevrelerinde gördükleri tam ailelerin çocuklarına baba yokluğunu hissettireceği ya da çevrelerinin kendileri hakkında dedikodu yapacağı endişesi ve dış çevrenin bekar anne olmaları dolayısıyla tehdit olarak algılanması boşanmış kadınların iş yerinde, mahalle ve diğer sosyal çevrelerinde özellikle erkeklerle olmak üzere ilişki kurmaktan kaçınma- 
larına sebep olur (Tek Ebeveynli Aileler, 2011, 134-135). Boşanmış kadınların boşanma sonrası ilişkilerine sınırlama getirmeleri, illa ki bilinçli bir eylem ya da karar almanın sonucunda gerçekleşmeyip, evliliğin sona ermiş olmasının yarattığı doğal bir sonuç da olabilir.

Evliliğin sona ermesiyle birlikte kadın, mekânsal bir hareketlilik içinde yaşamını düzenlemeye başlar. Boşanmanın sebep olduğu ekonomik zorlukların çiftleri eski sosyal çevrelerinin olduğu evlerinden taşınmak zorunda bırakması, yeni bir işe başlama ya da iş değiştirme zorunluluğu, ekonomik kazanımın azalması da bu ilişkilerin sınırlandırılmasında etkili olur (Clarke-Stewart, \& Brentano, 2006, 69-70). Arkadaşlığın sonlandırılması kararı boşanmış bireyin kendisine ait olabildiği gibi arkadaşının da kararı olabilir.

Mutlu bir evliliği olan bireyler, benzer problemlerin açıkça ortaya konulması nedeniyle boşanmaların yaşanmaya başladığı bir arkadaş çevresi içinde huzursuzluk duymaya başlarlar. İlişkilerinde yaşanan bir problem nedeniyle ayrılan bireylerin boşanmaları benzer problemleri yaşayan arkadaş çevreleri için de örnek oluşturarak bir domino etkisi yaratır. Bu nedenle boşanmayı deneyimleyen bireylerin arkadaş çevreleri boşanmış bireyleri genellikle kendi evlilikleri için bir tehdit olarak algılama ve dolayısıyla da arkadaşlıklarını sonlandırma eğilimindedirler (Coates, 2008, 200).

Boşanma sonrasında bireyler, kendilerine dayanışma sağlayacak yeni bir sosyal çevre ve yeni arkadaşlıklar kurmaktan ziyade, eski eşlerinden uzaklaşmalarını sağlamada en büyük araç olan başka biriyle romantik bir ilişki kurma eğilimi gösterirler. Çoğu boşanmış birey, boşanmanın ilk yılında bu türden ilişkilere başlar (Clarke-Stewart, \& Brentano, 2006, 70-71). Ancak boşanma kaynaklı ekonomik sıkıntı yaşayan kadınların, ekonomik yoksunluklarıyla bağlantılı olarak üyesi oldukları sosyal sınıfa ait kimliklerinin kesin bir sarsıntı geçirmesinin (Newman, $2009,394)$ yanı sıra iş ve çocuk bakımı gibi birçok sorumluluk üstlenmeleri, boşanmanın kendilerine duydukları güveni zedelemesi ve yaralanmaktan korkmaları sosyal aktivitelerini kısıtlayarak, özel ilişkiler kurmalarını zor hale getirir. Boşanma sonrası kadınlar, eski çevrelerine bir sınırlama getirdikleri gibi yeni kurdukları ilişkilerinde de daha seçici bir tutum sergilemekte ve yeni arkadaşlarını çoğunlukla kendileri gibi evliliklerinde problemleri olan kişilerden ya da evli olmayan bireylerden seçmektedirler (Clarke-Stewart, \& Brentano, 2006, 70-71). Nedeni ne olursa olsun boşanmış kadınlar evli hemcinslerine göre daha izole bir yaşam sürerler ve bu durum onların daha yalnız hissetmelerine sebep olur.

Boşanma ile birlikte kadın açısından gerek maddi gerekse manevi desteğe daha çok ihtiyaç duyulan bir süreç başlamaktadır. Kadınların, boşanma sonrasında aileleri ya da arkadaşları tarafından hoşgörü ile kabulleri, boşanma sonrasında statülerinde etkili olduğu gibi, bu yeni yaşam biçiminde karşılaştıkları zorluklarla mücadelelerinde de daha güçlü olmalarına yardımcı olur. Boşanmanın ardından yaşanan süreç, ayrıca kadınların bu çevreleriyle ilişkileri aracılığıyla boşanmalarını değerlendirme ve kendilerini algılama biçimlerine de yansıması bakımından önemlidir.

Boşanma süreci ve sonrası gerek bireyler gerekse yaşam biçimi açısından köklü bir değişimi beraberinde getirmektedir. Boşanmanın ardından kötü giden evliliklerine son veren kadınların bağlarından ve bağlılıklarından kurtularak bireyselleşip, özgürleşeceği düşünülmektedir. Oysa bunun aksi durumlar yani boşanan kadının bireyselliğinin ve özgürlüğünün kısıtlandığı durumlar da mevcuttur. Yılmaz ve Fidan'ın boşanma sonrasında kadının sosyal yaşamda ve özellikle iş yaşamında karşı karşıya kaldığı yeni koşulları ve buna uyum sağlama becerisini ortaya koymak amacıyla 50 boşanmış kadınla yaptıkları kalitatif nitelikli çalışmalarında boşanmayla birlikte kadını kısıtlayan kaynakların başında \%40 oranında kendilerinin geldiği ortaya konulmuştur. Kadınların özgürlüğünü kısıtlayan diğer kaynaklarsa; aileleri (anne, baba, kardeş, akraba), 
toplum ve boşandığ 1 eşleridir. Kadınların kendi özgürlüklerini kısıtlamalarının nedenleri; farklı kaynaklardan gelen yaşamlarına yönelik müdahale ve baskılara karşılık kendilerini korumaktır (Yılmaz, \& Fidan, 2006, 56-57). Bununla birlikte, boşanmış kadınlar zaman içinde eşlerinden ayrı da bir hayat sürdürebildiklerini, kendilerine çocuklarıyla yepyeni bir hayat kurabildiklerini fark edebilirler. Duygu ve düşünceleri zamanla olumlu yönde değişen bekar annelerin çocuklarıyla birlikte kurdukları bu yeni hayatlarındaki stres kaynakları da daha az olur. Çünkü çoğunlukla şiddetli geçimsizlik, duygusal ve fiziksel şiddet ve ekonomik sorunlar gibi nedenlerle boşanan annelerin evlilik sonrası yaşantıları daha huzurlu ve mutlu olur (Tek Ebeveynli Aileler, 2011, 87-89). Boşanma kadınlar için etkileri sadece olumsuz olan bir süreç değildir. Boşanan kadınların boşanma sonrası kırılganlıkları erkeklere oranla daha fazla olduğu gibi, boşanmanın sebep olduğu olumlu gelişmeler de kadınlar için söz konusudur. Boşanan kadınlar boşanmanın iyi tarafı olarak niteledikleri yeni bir bağımsızlık duygusu ve kendine güven deneyimleyebilmektedirler (Clarke-Stewart, \& Brentano, 2006, 91-92). Üstelik evliliğini boşanmayla noktalayan çiftlerin bir kısmı yeniden evlenmeyi de deneyebilmektedir.

Newman boşanmalar kadar boşanma sonrası yeniden evlenmelerin de yaygın olduğuna dikkat çekerek yeniden evlilik oranlarındaki yüksekliği, kötü giden evlilikler içerisindeki bireylerin boşanmayı bir çözüm olarak görmelerine karşın ilk evliliklerine dair kötü deneyimlerinin evliliğe yönelik olumsuz tavırlar geliştirmelerine yol açmamasıyla açılar $(2009,411)$. Bununla birlikte, yeniden evlilik konusundaki tutumlar, boşanmanın ardından geçen süreye, yaşa ve cinsiyete bağl1 olarak farkl111klar gösterir.

Boşanmanın yol açtığı değişikliklere karşı kendilerini izole etmede kadınlardan daha iyi olan ve özellikle orta yaşlarındalarsa yüksek bir yeniden evlenme eğilimi gösteren erkeklerin aksine istatistikler yaşlı kadınlarda yeniden evlilik oranlarının çok daha düşük olduğunu göstermektedir (Coates, 2008, 196-197). Yaş faktörü yeniden evlilikler üzerinde etkili olduğu kadar boşanmalardan etkilenim düzeyleri söz konusu olduğunda da önemlidir.

Boşandıktan sonra eğitimlerini sürdürebilecek, yeni bir iş olanağ1 elde edebilecek, hayatlarında önemli değişiklikler yapabilecek kadar kendine güvenli, enerjik, değişime hazır hisseden genç kadınlar için yeni birileriyle ilişki kurmak da daha kolaydır. Dolayısıyla yeniden evlenebileceklerini ve yaptıkları yeni seçimin daha mantıklı olacağını düşünmeleri onların boşanma sonrası hayata daha olumlu bakmalarına yardımcı olur. Boşanma sürecini kendilerini olgunlaştıran, kişisel gelişimlerini destekleyen bir süreç olarak görme eğiliminde olan genç kadınların aksine evliliğini bitiren kadınlardan 40'lı yaşlar ve üzerinde olanlar için bu süreç çok daha stresli geçer. Kırklı yaşlardaki kadınlar boşanmalarının ardından maddi ve manevi tatmin sağlayan bir iş bulmakta zorlanmalarının (Coates, 2008, 61) yanı sıra yalnızlık kaygısı taşırlar. Çocuklarının yetişkin birer birey olarak evden ayrılmalarıyla yalnızlıklarının pekişeceği endişesini duyan bekar annelerin çocuklarının evden ayrılması ayrıca ekonomik güvencelerini de kaybettikleri hissine kapılmalarına sebep olur (Tek Ebeveynli Aileler, 2011, 140).

Ailenin tüm bireylerini pek çok açıdan olumsuz etkileyen boşanmalar, özellikle kadınlar için birçok sıkıntıyı beraberinde getirirken onların ekonomik, sosyal ve duygusal yaşama uyum sağlamakta da zorlanmalarına sebep olur. Kadınların çalışıp çalışmaması, aile ve arkadaş çevreleriyle olan ilişkileri, yaşları, çocuk sahibi olup olmamaları vb faktörler boşanma sonrası sürecin başarılı bir şekilde atlatılabilmesi üzerinde oldukça etkilidir.

\section{c) Araştırmanın Yöntemi}

Boşanma öncesi ve sonrası süreçte kadınların yaşadıkları deneyimleri araştırmayı amaçlayan bu çalışma Antalya'da akademisyen olarak çalışan kadınlar örneğinde gerçekleştirilmiştir. Boşanmış 
kadınlara ulaşmaktaki güçlük ve kadınların ailenin mahrem konularını paylaşma konusunda gösterdiği çekingenlik nedeniyle Rastlantısal Kartopu Örnekleme tekniğinden yararlanılmıştır.

Veri toplama tekniği olarak araştırma sorununa ilişkin yüzeysel bilgiden çok, sorun alanındaki kişilerin görüş, düşünce, fikir, bakış açısı ve deneyimlerinin alınmasına olanak sağlayan "derinlemesine görüşme" tekniği tercih edilmiştir. Akademisyen kadınlarla yapılan araştırmada, kadınların boşanmalarının ardında yatan nedenlerin belirlenmesi, boşanma sonrası yaşadıkları sorunların neler olduğunun ve akademisyen kadınların boşanma sonrası kendilerini nasıl konumlandırdıklarının ortaya konulabilmesi amacıyla, Akdeniz Üniversitesi'nin çeşitli fakültelerinden ulaşılabilen ve çalışmaya katılmakta gönüllü olan akademisyen kadınlarla toplam 21 derinlemesine görüşme gerçekleştirilmiştir.

Boşanmış akademisyen kadınların boşanma öncesi ve sonrasında karşılaştıkları sorunlar, bu sorunların nedenleri ve sorunlarla başa çıkma ve çözüm mekanizmalarının araştırıldığı çalışmada kadınların öznel deneyimlerini sosyal, psikolojik ve ekonomik boyutlarıla derinlemesine araştırabilmek için veriler iki ana tema ve alt temalar altında toplanarak aşağıdaki gibi belirlenmiştir. Analiz gereği anlatım temalara ayrılıp sunulsa da tüm temaların birbiriyle ilişkili ve iç içe geçmiş bir halde olduğunu belirtmekte fayda vardır.

\section{Evlilik sürecine iliş̧in özellikler:}

- Evliliğin süresi

- Evlilik kararının alınış biçimi

- Evlenme biçimleri

- Eş ve çocuklarla kurulan ilişkilerin şekli

- Evliliğe ilişkin deneyimler

- Eşlerin sorunlar karşısındaki tutumları

\section{Boșanma sonrası sürece ilișkin özellikler:}

- Boşanma sonrası ailenin yapısı ve tutumu

- Dayanışma örüntüleri ve sosyal ilişkilerin biçimi

- Kendini konumlandırma ve boşanma algisi

- Boşanma sonrası karşılaşılan sorunlar ve başa çıkma stratejileri

- Geleceğe yönelik beklentiler

$\mathrm{Bu}$ iki temanın dışında görüşmeye katılan kadınların yaş, doğdukları şehir, akademik kariyerin hangi basamağında oldukları, çocuk sayısı vb. gibi aile ve evlilik yaşamını etkileyebilecek sosyo-demografik veriler de toplanmıştır.

Araştırmanın örneklemini oluşturan akademisyen kadınların eşlerinin öğrenim durumları lisans ve lisansüstünde yoğunlaşmakta olup, söz konusu eşler serbest meslek, akademisyenlik, öğretmenlik, memuriyet ve de subaylık gibi belli bir gelir getiren ve statüsü olan işlerle meşguldür.

Araştırmaya katılan kadınların evlilik süreleri irdelendiğinde, kadınların daha çok evliliklerinin 14. yılından sonra boşandıkları tespit edilmiştir. Araştırmaya katılan kadınların büyük çoğunluğunun (9 kadın) evliliği 11-15 yıl sürmüştür. Benzer yoğunluk, evliliklerini 3 ve 5. yılları arasında sona erdiren kadınlar arasında da görülmektedir (6 kadın). Görüşülen kadınlardan yalnızca 1'i evliliğinin 6. yılında boşandığını belirtmiştir. 5 kadının evliliklerinin 17. ve 24. yılları arasında boşandıkları belirlenirken, 3 yıldan önce evliliğini bitiren kadın akademisyene rastlanmamıştır. Türkiye'de boşanmalar en fazla evliliğin ilk beş yılında 
gerçekleşmesine karşın bu çalışmada ise en fazla 11-15 yılları arasında yoğunlaşma görülmüştür. Bu durumun sahip olunan çocuklarla ilgili olabileceği düşünülebilir. Şöyle ki araştırmada ilk üç yılda boşanan kadın bulunmazken 3-5 yıl arasında boşanan kadınların (6 kadın) 5'inin çocuğunun olmadığı gözlenmiş̧ir. $\mathrm{Bu}$ bağlamda toplumun geneline göre daha eğitimli olan akademisyen kadınların boşanma sonrası çocuklarının bu durumdan daha az mağdur olmalarını sağlayabilmek için çocuklarının belli bir olgunluğa erişmelerini bekledikleri tahmin edilebilir.

Araştırmaya katılan kadınların boşandıkları yıllar incelendiğinde özellikle 2010 yılındaki artışın 2011 ve 2013 yıllarında da devam ettiği görülmektedir. Araştırma kapsamında görüşülen akademisyen kadınların çoğunluğu (11 kadın) 2000 ve 2009 yılları arasında boşanmışlardır. Boşanmaların yarıya yakını (9 kadın) ise 2010, 2011, 2012 ve 2013'ü kapsayan dört yıllık süreçte gerçekleşmiştir. Görüşülen kadınlardan yalnızca 1'inin boşanmasının üzerinden 21 yıl geçtiği belirlenmiştir.

\section{Alan Araştırmasından Elde Edilen Verilerinin Sunuluşu}

\section{Evlilik Sürecine İlișkin Özellikler}

\section{Evlenme Biçimi ve Evliliğe Karar Verme}

Çiftlerin evlenme şekillerinin ve evlenmeden önce birbirlerini yeterince tanımış olmalarının sağlıklı bir aile yapısının kurulmasına katkısı olabilecek değişkenler olduğu varsayımıyla araştırma kapsamında görüşülen 21 akademisyen kadına eşleriyle nasıl tanışıp evlendikleri sorusu yöneltilmiştir. Araştırmanın en önemli bulgularından birisi, yapılan evliliklerin hemen hepsinin (19 kadın) sevgiye dayalı ve arkadaşlık ederek gerçekleştirilen evlilikler olmasıdır. Görücü usulü gerçekleştirilen iki evlilikte de yine çiftlerin birbirlerini karşılıklı tanımaları için bir araya gelip görüşmeleri desteklenmiştir.

Sağlıklı bir evliliğin kurulmasında bireylerin kendi rızalarının yanı sıra, evlenmeleri için soy ailelerinin ve yakın akraba ve arkadaş çevrelerinin onayının olması da önemli bir değişkendir. Çiftlerin evliliğine bu yakınlarından büyük çoğunluğunun onay vermemesi halinde eşler evliliği sürdürmek ve bu amaçla fedakârlıklarda bulunmak konusunda gönülsüz olabilirler (Battal, 2008, 107-108). Bu nedenle görüşülen akademisyen kadınların evliliklerini ailelerinin onaylayıp onaylamadığı sorgulanmış ve hepsinin ailelerinin evlilik kararlarını kendilerine bıraktıkları belirlenmiştir. Ancak aşağıdaki örnek ifadelerde de izleneceği gibi görüşülen kadınlardan bazılarının yaşlarının eşlerinden küçük olması (2 kadın), eşleriyle aralarında kültür farkının (4 kadın) ya da mezhepsel farklılıkların (1 kadın) bulunması, eşlerini ya da ailesini hiç tanımıyor olmaları (1 kadın) ve karakter yapılarındaki uyumsuzluk (1 kadın) gibi gerekçelerle başta bir tepkiyle karşılaştıkları belirlenmiş olup söz konusu akademisyen kadınlar yine de ailelerinin evlenmelerine bir müdahalede bulunmadıklarını belirtmişlerdir.

“...hayır. Yaş farkından dolayı ailem eşimle evliliğimi onaylamadı ama onların onayına ihtiyaç duymadan ben bu kararı alıp evlendim...” (G12, 37 yaş, b).

(Katılımcıların ifadelerinden sonra parantez içinde $\mathrm{a}$ ya da $\mathrm{b}$ işaretlemelerinin kullanılması, yaşıt olan akademisyen kadınların aynı kişi olarak değerlendirilmesiyle ortaya çıkabilecek karışıklı̆̆ın önlenebilmesi içindir)

“...ailem onayladı. Yani daha doğrusu aslında başta çok sıcak bakmadılar; çünkü hiç tanımadıkları biri ile ben birdenbire evlenmeye karar verdim, öncesinde X'i tanımıyorlardı. O yüzden nasıl olur, erken değil 
mi dediler, ama genelde benim kararlarıma güvenirler, o yüzden çok büyük bir problem olmadı bu bizim aramızda...” (G21, 31 yaş).

Evliliğin kurulması aşamasında müstakbel eşlerin sahip oldukları benzer sosyal ve kültürel özellikleri evliliğin sağlıklı yürütülebilmesinde önemli rol oynayan faktörler olarak değerlendiren ailelerin kültür, karakter, yapı ya da mezhepsel farklılıkların evlilikte problem yaratacağını düşünerek, çocuklarının yapısal farklılıkların bulunduğu bu gibi durumlarda evliliklerini onaylamadıkları görülmüştür.

Araştırmanın bulguları, hem evlilik sürecinde flörtün yaygın bir tanıma aracı olarak kullanıldığını hem de görüşülen kadınların flörte sıcak baktıklarını göstermektedir. Ayrıca eskiden yaygın ve geçerli bir evlenme yöntemi olan görüşmeksizin evlenme anlamında görücü usulü evliliklerin tercih edilmediği görülmektedir. Kadınların büyük çoğunluğu görücü usulü yerine kendileri tanışıp belli bir süre eşlerini tanıdıktan sonra evlenmelerine karşın evlilikleri boşanmayla sonuçlanmıştır.

\section{Evlilik Sürecinde Eșler Arası İlișkiler ve Boșanma Nedenleri}

Görüşülen akademisyen kadınların hemen hepsi (19 kadın) evlilik gerçekleştirmeden önce eşlerini tanıyabilecekleri uzun bir flört dönemini geçirmiş olduklarını ifade etmelerine karşın çalışmada elde edilen bulgulardan biri, evliliğin boşanmayla sonuçlanmasında belirleyici faktörlerden birisinin eşler arası iletişimsizlik olduğudur. Görüşülen kadınların hemen hepsi eşleriyle birbirlerini yeterince uzun süredir tanıyor olduklarını belirtmelerine rağmen, evlilikleri sürecinde eşlerinin hiç bilmedikleri başka özellikleriyle karşılaşmaları nedeniyle hayal kırıklığ yaşadıklarını ifade etmişlerdir. Çiftlerin birbirlerini eksik veya yanlış tanımalarının yanı sıra, her ikisinin de farklı bakış açıları, farklı tüketim ve eğlence alışkanlıklarına sahip olmalarının iletişim kopukluğuna sebep olduğu belirlenmiştir.

\section{“...iletişim problemleri diyebilirim, iletişim problemi oldu. İkimiz de yetişkindik, ikimiz de 30'undan sonra evlenmiş insanlardik ama yine de iletişim sorunu yasadık açıkçası.... tabi artık iletişimi kesinlikle kurama- dı ̆̆ımı anladĭ̆ım an, bu ilişkinin böyle gitmemesi gerektiğini, bu sorunla yaşanmaması gerektiğini düşündüm ama artık derdimi anlatamadı̆̆ımı, anlatamayacağımı anlamıştım, öyle diyeyim...” (G20, 38 yaş, b). \\ “...biz eşimle arkadaş olamadık birbirimize, dost olmayı beceremedik. Bir paylaşımımız olmadı o yüzden. Evliliğimiz de bu şekilde geçti bir paylaşım olmadan, bir dostluk kurulamadan...” (G10, 47 yaş, b).}

Kadınların boşanma deneyimlerine ilişkin yukarıdaki örnek ifadelerde de irdelendiği gibi, iletişim kopukluğu görüşülen akademisyen kadınların bazılarında ev içinde eşleriyle arkadaşlığın kurulamaması ve paylaşımın olmaması nedeniyle duygusal bağların da zayıflaması biçiminde karşılık bulmuştur.

Daha çok eşlerin bakış açılarının farklılığından kaynaklanan iletişim kopukluğunu tetikleyen faktörlerin başında ise eşlerin birbirlerini ve ev içindeki rollerini ihmal etmeleri gelmektedir. Araştırmanın verileri değerlendirildiğinde yoğun iş temposu nedeniyle çiftlerin evlerine zaman ayıramamasının, eşlerin ve evin ihmaline ve dolayısıyla da eşler arasında iletişim kopukluğuna yol açarak boşanmaları tetiklediği ortaya konulmuştur. Erkeklerin evi ve ev içindeki rollerini ihmal etmeleri, evlilikte yaşanan problemlerin kaynağı olabildiği gibi, erkeklere oranla çok daha düşük oranda da olsa, kadının çalışmasının ev içinde sorunlara sebep olduğu örneklere de 
rastlanmıştır. $\mathrm{Bu}$ çalışma kapsamında görüşülen akademisyen kadınların ev dışında çalışma hayatında aktif olarak yer almalarının, boşanmalarına sebep olabilecek bir problem yaratmadığını düşündükleri gözlenmiştir. Bununla birlikte kadınlar, eşlerinin çalışma hayatı ile birlikte artan sorumluluklarını göz ardı ederek ev içi işlerde ve çocuk bakımı konularında paylaşımcı bir rol üstlenmenin aksine, değişime direnç göstererek paylaşımdan uzak bir tutum sergidiklerini, bunun da evliliğin sağlıklı bir biçimde yürütülmesini olumsuz olarak etkilediğini ifade etmişlerdir.

“...rolleri karıştırlyorlar, çocuğunuz gibi davranıyorlar bir süre sonra herhalde. Biz mi şımartıyoruz, biz mi üstleniyoruz çok sorumluluk bilmiyorum. Belki öyle oldu ben çünkü çok sorumluluk aldım. Yani evin bütün yükünü ben aldım açıkçası; o akşamları, geceleri uğruyordu 3, 4 saat temel ihtiyaçlarını gideriyordu yemek, içmek, duş bilmem ne ondan sonra gidiyordu, Yani erkek bu...” (G9, 47 yaş, a).

“...şimdi eskiden kadınlar benim anneannem olsun falan filan sadece evde çalışlyorlarmış, çoluğa çocuğa baklyorlar adam getiriyor eve bir şekilde bu şekilde idare ediyorlar, fakat bizler eşitlik kavramı altında tuttuk çalışmaya başladık. Çalışmaya başladığımız noktada da ama aynı şekilde evin içerisindeki sorumluluklar bölüşülmedi ama erkekler de dedi ki kardeşim eşitlik değil mi siz de çalışacaksınız, öyle bir şey. Ki hani kadının özgürlüğ̈̈ kadının kendi özgürlügünü zincir altına almaya başladı, bana göre öyle, en büyük sorun o. Kadın da bu noktada böyle patlamalar falan yaşadıkça, ettikçe sorunlar daha da büyüyor...” (G5, 34 yaş).

Yukarıdaki örnek ifadelerde de görüldügü üzere, görüşülen akademisyen kadınlardan bazılarının boşanmalarında, çalışma hayatı ile birlikte artan sorumluluklarının eşleri tarafından göz ardı edilmesi ve artan iş yüklerine rağmen eşlerinin paylaşımdan uzak tutumlar sergilemeleri etkili olmuştur. Ayrıca akademisyen kadınların eşlerinin yoğun iş tempoları nedeniyle evlerine zaman ayıramamasının, eşlerin ve evin ihmaline ve dolayısıyla da eşler arasında iletişim kopukluğuna yol açarak boşanmaları tetiklediği ortaya konulmuştur.

Araştırmanın bu verileri, daha önce kavramsal çerçevede tartış1lan Telsiz (1995, 83-84), Aydın, \& Baran'ın (2010, 117-118) kadın ve erkeklerin ev işleriyle ilgili sorumluluğu paylaşımının eşit düzeyde olmamasının kadınların rol çatışması yaşamalarına sebep olabildiği gibi, evliliklerde sorunları da tetiklediğine ilişkin görüşlerini desteklemektedir.

Yukarıdaki görüşlere paralel bir biçimde araştırmanın da en önemli bulgularından biri, "evlilikte beklentilerinin karşılanmaması"nın boşanmış akademisyen kadınların en sık gösterdikleri boşanma gerekçesi olmasıdır. Psiko-sosyal doyumun her an yaşandığı, karşılıklı olarak romantik sevgi, dostluk ve sırdaşlık temeline dayalı olan ve uyum içinde sürdürülen bir evlilik hayatı olacağını düşünerek evlilik gerçekleştiren kadınlar, evlilik yoluyla bu ihtiyaçlarının karşılanmadığını görüp bir hayal kırıklığı yaşadıklarını ve bu durumun boşanma düşüncesini gündemlerine getirdiğini ifade etmişlerdir. Evlilikte beklentilerin karşılanamaması gerginlikleri, gerginlikler de çatışmaları kaçınılmaz kılmaktadır. Araştırmadan elde edilen bu bulgular, Parrillo, Stimson \& Stimson'un $(1995,293)$ evlilik ilişkisi içerisindeki bireylerin bir başka kişiyle birleşme aracıllğıyla gerçekleşen bir kişisel tatmin peşinde olmaları bakımından duygusal ihtiyaçlarının karşılanamadığı durumlarda bu birleşmenin temelinin sarsılacağı yönündeki görüşlerini desteklemektedir.

$$
\text { “...yani aslında bu bildiğimiz anlamda şeyler yok hani şiddet, dayak }
$$


ondan sonra hakaret vesaire yok bizim ilişkimizde. Ben hatta şey diyorum; benim evliliğim sessizce yıkıld, hiç tartı̧̧ma olmaksızın, konuşma olmaksızın. Bu dişarıdan kolay görülebilir, hatta bunu yaşayan kadın için şımarlklık olarak da algllanabilir. Çünkü şiddet yok, içki yok adam evine geliyor, daha ne istiyorsun gibi bakılabilir. Ama öte taraftan son derece bunaltıcl, ruhu yipratıcı ve doyumsuzluğa neden olan bir boyutu vardl bunun. Çünkü istiyorsunuz ki birileriyle bir şey paylaşayım. ...aradiğını bulamamayla ilgili hani duygusal doyumu sağlayamamayla ilgili bir sorunlar silsilesi ondan sonra başladı. O'nun beklentilerini ben karşıladim muhtemelen, öyle görünüyordu, ama bir müddet sonra O benim beklentilerimi karşılayamamaya başladı...” (G14, 51 yaş, a).

“...bir erkekten beklediğim hiçbir şey yoktu, yani hani güzel bir söz, bir jest, romantizm hiçbir şey yoktu yani. Bunlar da hani slkıntı veriyordu, biraz uzaklaşmamiza neden oldu...” (G18, 40 yaş, a).

Boşanma deneyimlerine ilişkin örnek ifadelerde de irdelendiği üzere, akademisyen kadınların bazıları duygusal tatminin sağlandığı bir evlilik beklentisi içerisindelerken aşağıdaki örnekte de yer verildiği gibi bazı kadınların evlilik beklentileri, kendilerini evlilik ilişkisi içinde duygusal eşitlik ve tatmin talep eden bir birey olarak konumlandırmaları biçiminde karşılık bulmuştur.

“...benim ne istediğimin aslında çok fazla önemi yoktu ilişkimizde. Hep bir baskın taraf vardır ya, O baskın taraftı ve biz O'na göre yaşlyorduk ve bu bir zaman sonra beni çok yordu. Yorduğu noktada da "Ne yaplyorum ben, ne oluyor bize, bu hayat böyle mi geçecek?” demeye başladım ve bu problemlerimiz patlak verdi, bu...” (G21, 31 yaş).

Kurdukları evliliklerini mutlu temeller üzerine yerleştirme beklentisi içerisinde olan kadınların beklentilerini yükselten kaynakların ise, çalışma hayatında aktif olarak yer almaları ve evlilik yoluyla kurdukları birlikteliklerinin aktif bir öznesi olduklarının bilincine varmaları olduğu saptanmıştır. Çalışma hayatında aktif olarak yer almaları dolayısıyla bir yandan ekonomik olarak güvence elde etmiş olan kadınların kendilerine güvenlerinin arttığı ve bunun doğal bir sonucu olarak da kendilerini güç ve eşitlik talep eden bir özne olarak konumlandırdıkları belirlenmiştir. Bu bakımdan her ne kadar çalışma kapsamında görüşülen akademisyen kadınlar ev dışında çalışma hayatında aktif olarak yer almalarının boşanmalarına sebep olabilecek bir problem yaratmadığı görüşünde olsalar da araştırmadan elde edilen veriler 1şı̆ı̆ında kadının çalışma yaşamının evlilik içi ilişkileri doğrudan ya da dolaylı olarak olumsuz etkilediği söylenebilir.

\section{Sorunlar Karşısındaki Tutum}

Evliliklerde hem ev içinde hem de ev dışı sosyal aktivitelere ilişkin olarak duygusal doyumu sağlayan taraf olmaları nedeniyle kadınlar evliliklerinin sıkıntılı konularının tartışılıp bir karara bağlanması sorumluluğunu almaktadırlar (Coates, 2008, 37). Kadınların evliliklerinin duygusal denetimini ellerinde tutmaları, bir yandan evliliklerindeki problemleri eşlerine göre daha erken fark etmelerine olanak sağlarken bu durum kadınların aile içi problemleri tartışmaya açan taraf olma olasılıklarını artırmaktadır (Amato, \& Previti, 2003, 604). Thompson \& Walker kadınların erkeklere göre ilişkilerini yakından incelemeye daha yatkın olmalarının, ilişkilerindeki sorunları daha erken fark etmelerine ve bu sorunları çözmeye yönelik eşleriyle tartışma eğilimi göstermelerine yol açtığını belirtir. Erkekler aile içinde gerçekleşebilecek açık bir tartışmadan 
kaçınmaları nedeniyle genellikle aile içindeki sorunları görmezden gelme eğilimi gösterirlerken; kadınlar üstü örtülen sorunları gündeme getirmelerinin yanı sıra soruna yönelik tatmin edici bir çözüm bulmadan da o tartışmanın bitmesine izin vermemektedirler $(1989,848)$. Bunun yanı sıra kadınlar evlilik içi sorunların çözüme ulaşabilmesi için, evlilik uzmanlarına danışma konusunda da erkeklere oranla on kat daha isteklidirler. Dolayısıyla evliliğin duygusal tatminini sağlayan kadının üstlendiği bu sorumluluklarından vazgeçmesi, birçok evliliğin sarsılmasına neden olmaktadır (Coates, 2008, 37-40). Bu bakımdan eşlerin evlilik sürecinde karşılaşılan sorunlara yaklaşım biçimleri ve bu sorunlar karşısındaki tutumlarını saptamak, aile içindeki etkileşimin nasıl olduğu ve iletişim düzeyi hakkında bir fikir vermesi bakımından önemli görülmüştür.

Boşanmış akademisyen kadınlarla yapılan derinlemesine görüşmelerden elde edilen veriler, "aile içi etkileşim" ve "eşlerin sorunlar karşısındaki tutumları" bağlamında boşanma olgusuyla ilgili olarak daha önce yapılan çalışmaların bulgularını destekler niteliktedir. Araştırmaya kat1lan akademisyen kadınlar evlilikte yaşanan sorunlar karşısında daha yapıcı davrandıklarını, evliliklerini yürütmeye yönelik daha aktif olduklarını belirtirlerken, eşlerinin iletişime daha kapalı olduklarını, aşağıdaki örnek ifadede de görüldüğü üzere zaman zaman da iletişimi engelleyici tavırlar sergilediklerini vurgulamışlardır.

“...ben eşimle hiç oturup konuşamadım, acı olan bu. Kapıyı örttüğümde hep hopluyor adam... "Niye hopluyorsun, şuraya otur insan gibi konuşalım. Bă̆ırma yani, niye bağırıyorsun." Çocuk oldu bă̆ırıyor. Yani hiç mantıklı değildi...” (G13, 57 yaş).

Ev içinde daha çok sorunların üstünü örtme, karşılaştıkları problemleri yok sayma gibi yöntemler izleyen eşlerinin aksine kadınların büyük çoğunluğu (15 kadın) eşleriyle konuşma, mutsuzluklarını dile getirme ve buna bir çözüm arama yoluna gittiklerini belirtmişlerdir. Kendileri tek başlarına çözüm üretemediklerine inanan bazı kadınlar çözüm sürecinde aile büyüklerinden destek aldıklarını belirtmekle birlikte daha çok aile sorunlarıyla ilgilenen uzmanlardan yardım alma girişiminde bulunmuşlardır. Ancak bu gayretlerinin kişisel bir çaba olarak kaldığını ve sorunların çözümünde etkili olamadığını belirtmişlerdir.

Kadınların sorunlarını aileye yansıtmaları ya da evlilikteki sorunlarının arkadaş çevresinde konuşulması boşanmalarında tetikleyici de olabilmektedir. Nitekim aşağıdaki örnek ifadede de görüldüğü üzere, görüşülen kadınlardan bazıları arkadaş çevrelerinin sorunlara çözüm önerisi olarak boşanma seçeneğini kendilerine sunduklarını belirtmişlerdir. Sonuç olarak evlilik içindeki sorunların çözümsüz kaldığ̣ görülmektedir. Çözümün üretilemediği buna karşl1ık çatışmaların giderek arttığı evliliklerin boşanmayla neticelendiği bulgulanmıştır.

“...benim çok sevdiğim bir hocam var, bana şöyle bir şey söyledi bir gün, böyle evliliğimle ilgili konuşuyoruz; "Hayat zaten çok uzun bir yol, bu yolda sırtındaki yükleri sirtından atmak gerekir" dedi bana. Bana o çok acayip etkili olmuştur, yani böyle tamamıyla karar vermemde..." (G5, 34 yaş)

Görüşülen kadınlardan bazıları evliliklerinin ilk zamanlarında sorunların çözümüne yönelik çok çabaladıklarını, sürekli eşleriyle konuşmaya çalıştıklarını ifade ederken, evliliklerinin son zamanlarında artık mücadele etmekten yılarak eşleri gibi sessiz kaldıklarını vurgulamışlardır.

“... zaman içerisinde de bu yolları denedikçe bir değişiklik olmaması sizi umutsuzluğa götürüyor ve sorunun çözülemeyeceğine inanıyorsunuz. Ve hani bu belki öğrenilmiş çaresizlik, belki boş vermişlik bir müddet sonra 


\section{aldırmazlık evresine geçiyorsunuz daha doğrusu. O da zaten boşanmaya en yakın nokta oluyor bana kalırsa..." (G14, 51 yaş, a).}

Çalışmanın saha kısmından elde edilen bu veriler, Kessler'in (1975) ayrışma evresine ilişkin görüşleriyle paralellik göstermektedir. Edinilen veriler, ayrışma evresindeki baskın tavrın umursamazlık olduğunu ve evlilik bağ ile bir arada bulunan eşlerin bu evrede sözel iletişimden ve yakınlaşmayı gerektiren ilişkilerden kaçınarak sessizliği sürdürme eğilimi gösterdiklerini, bazen de eşlerden biri veya ikisinin birden boşanma sonrası yaşamı düşünmeye başladığını belirten Kessler'in görüşlerini destekler.

Boşanma nedenleriyle ilgili olarak araştırmadan edinilen bulgular, boşanmanın tek bir faktörle açıklanamayacak kadar karmaşık, sosyal, kültürel, psikolojik ve ekonomik boyutları olan bir olgu olduğu yönündeki görüşleri desteklemektedir.

\section{Boşanma Sonrasi Sürece İlişkin Özellikler}

\section{Boşanmanın Ekonomik Boyutu}

Kadınların gelir düzeyinin boşanmaya karar verme sürecinde etkili olduğu kadar, boşanma sonrasında yaşamlarını idame ettirebilmeleri ve sosyal konumları açısından da önemli bir değişken olduğu saptanmıştır. Akademisyen kadınlar, boşanma öncesindeki gelir düzeyleri ile boşanma sonrasındaki gelir düzeyleri arasında çok büyük bir fark olmadığını ifade etmişlerdir. Belirtmeliyiz ki kadınların boşanma öncesinde ve sonrasında gelirlerinde büyük bir farkın olmamasının sebebi; araştırmanın örneklemini çalışma hayatında aktif olarak yer alan ortalama gelir düzeyine sahip akademisyen kadınların oluşturmasıdır. Dolayısıyla boşanmalarından önceki süreçte de çalışıyor pozisyonunda olan kadınların, boşanma sonrasında gelirlerinde büyük bir düşüş yaşanmadığı tespit edilmiştir. Bununla birlikte, görüşülen kadınların yarısı (10 kadın) boşanmanın hemen ardındaki süreçte çeşitli nedenlerle büyük bir maddi bunalım yaşadıklarını belirtmişlerdir. Boşanma sonrası süreçte kadınların maddi sıkıntı çekmelerinin en büyük sebebinin hemen hepsinin kocalarıyla yaşadıkları evlerinden ayrılarak yeni bir hayat kurmak zorunda kalmaları olduğu belirlenmiştir. Boşanmış kadınlardan büyük çoğunluğu evlerinden tek bir eşya dahi almadan kıyafetleriyle evden çıkıp gittiklerini belirtmişlerdir. Kadınları maddi sıkıntıya sokan bir diğer nedenin evlilikleri süresince hiçbir birikim yapmamış olmaları ve biranda her şeyi yeniden almak durumunda kalmaları olduğu belirlenmiştir.

\section{“...çok yaşadım. Tabi ki. Çok ciddi sıkıntılar yaşadım. Kitaplarımı sattım, böyle gümüşlerimi sattım, gümüş bilekliklerimi, altınlarımı. Bir sürü şey yani bir sürü şey sattım. Gerçekten, gerçekten ama ekmek para- mın olmadı̆̆ zamanlar vard ı yani...” (G 17, 32 yaş).}

Çalışmanın saha kısmına ilişkin bu veriler, Bohannon'un (1970) evlilik birliğinin sona ermesiyle karı kocanın ortak mülklerinin paylaşılması neticesinde ekonomik birikimlerinin ikiye bölünmesine ek olarak yaşanacak yeni bir ev bulunması, taşınma, yeni ayrı bir ev düzeni kurma gibi konuların uğraştırıcı olduğuna yönelik görüşlerini destekler. Ayrıca araştırmanın boşanma sonrası kadınların ekonomik sıkıntıya düştüklerine ilişkin bu verileri, Amato'nun (2000) boşanmış kadınların boşanmış erkekler ya da evli hemcinslerine göre daha kötü ve daha süreğen bir ekonomik bunalım içine girdikleri, bu ekonomik bunalımları süresince faturalarını ödeme ya da temel ihtiyaçlarına ulaşabilme imkanlarının bile kısıtlı olduğu yönündeki görüşünü de desteklemektedir.

Evlilikleri süresince eşlerinin çalışmaması dolayısıyla evin bütün yükünü taşıyan kadınlar bile boşanmanın ardından ekonomik bir sıkıntıya düştüklerini ifade etmişlerdir. Evliliği sonlan- 
dırma sürecinde, eşlerin birlikte aldıkları kredilerin borçlarına ek avukat ve mahkeme masraflarının, boşanma sonrası süreçte kadınların gelirlerini büyük oranda düşüren diğer kaynaklar olduğu belirlenmiştir.

“...onun dişında maddi elbette çok, bütün birikimim bittiği için tekrar sıfırdan başlamak zorunda kaldım. O anlamda ciddi bir sıkıntıydl... tabi avukata da biraz para vermek gerekiyordu. O zaman, 7 yll 8 yıl önce 2000 lira falan. Arkadaş olmasina rağmen ben neyse sizin ücretinizi ödeyeceğim dedim, o anlamda o da maddi bir sıkıntı oldu...” (G11, 37 yaş, a).

Kadınların boşanma sonrası ekonomik olarak dezavantajlı durumda olmalarının ardındaki temel nedenlerden birinin çocuk sahibi olmak olduğu anlaşılmıştır. Çocuk sahibi boşanmış kadınların hemen hepsi çocuğun sorumluluğunu üstlenmişlerdir. Boşanmayla birlikte ekonomik yük ve sorumlulukları anne ve babanın paylaştığı bir durumdan sadece annenin yüklendiği bir aile biçimine geçilmesi, diğer bir söylemle çift gelirle geçinen ailenin gelirinin teke düşmesi, örneklem içinde yer alan boşanmış akademisyen kadınların boşandıktan sonra büyük ekonomik sıkıntılar yaşamalarına sebep olmuştur.

“...biz çocuklarla evden annemin yanına gittik, $O$ tek başına yaşadiğ halde bizim evden çıkmadl, çocuklarımın da benim de düzenimizi bozdu. Ben annemin yanına geldim, ben annemin yanına gelir gelmez benim kardeşim anneme para göndermeyi kesti; ben zaten oradayım diye. İşin kötüsü fakat eski eşim kapıya gelip gelip bizim oturduğumuz evin kirasını benden almaya devam etti senin ă̆zını burnunu kırarım getir aşağıya kirayı falan şeklinde. Bu da çok büyük bir sorun olarak kaldı. O yüzden o dönemde inanılmaz zorluk, parasal açıdan inanılmaz zorluk çektim; çünkü tek maaş, 2 tane çocuk, iki ayrı evin gideri o dönemde beni mahvetti. En fazla parasızlık mahvetti...” (G5, 34 yaş).

Kadınların boşanma sonrası deneyimledikleri sıkıntılardan bir diğerinin depresyon olduğu belirlenmiştir. Depresyon nedeniyle çalışamayacak durumda olduklarını ve ücretsiz izne ayrıldıklarını söyleyen kadınlar olduğu gibi, bazı kadınlar bu süreci ancak psikolog yardımı (2 kadın) ya da ilaç tedavisiyle (2 kadın) atlattıklarını belirtmişlerdir. Aşağıdaki örnek ifadede de izlenebileceği gibi boşanma sonrası yaşanan depresyonun kadınların bu süreci daha zorlu geçirmelerinde etkili olmanın yanı sıra ekonomik sıkıntılarını da artırdı ğı saptanmıştır.

“...ben büyük bir travma geçirdim. Bir yll çalışamadım, mesleğime ara vermek zorunda kaldım... Bu biraz şeyime ara vermiş olmam, mesleki yaşamıma toparlanmak için, bu bende ciddi handikaplar yarattı mali açıdan...” (G15, 51 yaş, b).

Nafaka, boşanma sonrasında kadınların ekonomik açıdan mağduriyetini azaltacak kaynaklardan birisidir. Boşanma sonrasında hukuki açıdan kusurun büyük çoğunlukla erkekte bulunması ve çocuğun fiili bakımını kadının üstlenmesi nedeniyle nafaka alma hakkını çoğunlukla kadınlar elde etmektedir. Ancak araştırma kapsamında görüşülen 21 kadından büyük çoğunluğunun (15 kadın) eski eşlerinin boşandıktan sonra kendileri ya da çocukları için maddi/manevi destek sağlamadığı belirlenmiştir. Eşin düşük sosyo-ekonomik durumu, eski eşle iletişim kurmaktan kaçınma gibi gerekçelerle bazı akademisyen kadınların kendilerinin nafaka talebinde bulunmadıkları, nafaka talebinde bulunan bazılarının (4 kadın) ise ancak çok düşük meblağlarda nafaka aldıkları belirlenmiştir. Görüşülen kadınlardan 2'si mahkemenin çocukları için nafaka bağladığını ancak bu ödemenin hiç gerçekleşmediğini, bazıları da ödemelerin eksik ya da zamansız 
olduğunu belirtmiştir.

“...nafakayı, ben hani adamın nesi var ki nesini alacağım. Donu yok donunu mu alacă̆ım, öyle diyeyim. Ama şey tedbir olarak bunu bana hakim şey yaptl, tedbir olarak dedi en düşügünden bir şey koyalım dedi. 2 çocuk için 300 lira toplamda 300 lira nafaka bağlad, fakat bir kere bile vermedi şu güne kadar, bir kere bile vermedi...” (G5, 34 yaş).

Çalışmanın bu bulguları, 2011 yılında ASAGEM tarafından yürütülen ve çoğu kadının kocasının düşük sosyo-ekonomik durumu, boşandığı eşiyle muhatap olmayı istememe, nafakanın pazarlık malzemesi olmasından ya da kocasının tehdidiyle karşılaşmaktan kaçınma gibi gerekçelerle nafaka talebinde bulunmadığı, nafaka talebinde bulunan çoğu kadının ise, eski kocasının düşük sosyo ekonomik durumu yüzünden nafaka alamadığı ya da ancak çok düşük miktarlarda nafaka alabildiğinin belirlendiği çalışmanın bulgularıyla benzerlik göstermektedir.

\section{Boşanma Sonrası Ailenin Yapısı ve Ailenin Tutumu}

Araştırmadan elde edilen veriler 1şığında örneklem içinde yer alan kadınların önemli bir çoğunluğunun, boşanma sonrasında tek başına veya aile reisi olarak çocukları ile birlikte yaşadıkları, genel olarak boşanma sonrasında soy ailenin denetim ve koruyuculuğu altına girme eğiliminin, beklentilerden düşük olduğu saptanmıştır. Boşanma sonrası aile yanına taşınma oranındaki düşüklük, kadınların hepsinin aktif olarak çalışma hayatında yer almalarıyla açıklanabilir. Boşanma sonrasındaki ekonomik koşullar, kadınların yalnız yaşama konusundaki tercihlerini etkilemektedir. Bununla birlikte araştırma kapsamında görüşülen kadınların kendi evlerini açmalarını sağlayan esas etken ise, eğitim düzeyi ve mesleki statüdür. Yüksek eğitim düzeyine ve bununla bağlantılı olarak yüksek mesleki statüye sahip akademisyen kadınların eğitim ve mesleki statülerinin vermiş olduğu güvenle, geleneksel değerlerden görece bağımsız hareket ederek tercihlerini belirledikleri görülmüştür. Boşanma sonrasında kendi ebeveynleri ile birlikte yaşamak yerine ayrı ev tutup çocukları ile bağımsız yaşamayı tercih etmeleri, onların hem evli bulundukları hem de evliliklerinden önceki durumlarına göre daha bağımsız bir yaşam sürmelerine olanak tanır. Bu açıdan tek ebeveynlilik, kadınları güçlendiren bir süreç olarak değerlendirilebilir.

“...Çok iyi hissettim, çok özgür hissettim, çok huzurlu hissettim. Artık her şeyin kararını ben veriyorum...” (G1, 38 yaş, a).

“...ş̧imdi hiç olmazsa kendi gruplarımı kuruyorum hiç kimsenin benim üzerimde hükmü olmadı̆̆ için istediğim saatte çıkıyorum, istediğim saatte istediğim programı yapıyorum, çok daha özgürüm, çok daha rahatım yani. Eskiden olsa kaçta geldin, nerdesin O hesap sorardı. E şimdi hesap soran kimse yok ki...” (G9, 47 yaş, a).

Boşanmanın ardından ailesinin yanına taşındıklarını ifade eden kadınların gerekçeleri daha çok çocuk bakımı ya da ekonomik destek sağlamak olmuştur.

“...yani inanılmaz bir şey yani; ailem olmasaydı bir çocukla bu boşanmanın yükünü ben mümkün değil kaldıramazdım. Çünkü annem o kadar iyi baktı ki kızıma ve ben hiç gözüm arkada değil, istediğim zaman işime gittim, istediğim zaman arkadaşlarımla buluştum, istediğim zaman şehir dişına gittim, istediğim zaman tatile gittim. Sen ne istiyorsan yap biz hallederiz şeklinde...” (G11, 37 yaş, a). 
Yukarıda izlenen örnek ifadede de görüldüğü üzere, boşanmış akademisyen kadınlardan özellikle çocuk sahibi olanlar için aile desteği, çift gelirli aile modelinden tek gelirli ve tek ebeveynli aileye doğru yaşanan dönüşüm sürecinde kızlarına çocukların bakımı konusunda yardımcı olmak ve ekonomik olarak katkı sağlamak biçiminde karşılık bulmaktadır.

Araştırmanın kavramsal çerçevesinde belirtilen diğer çalışmaların bulgularının aksine, akademisyen kadınların ailelerinin boşanma sürecinde evliliğin sürdürülmesi yönünde baskıcı bir tavır sergileyerek kızlarına müdahalede bulunmadıkları belirlenmiştir.

“...en büyük şansım! Çevrem ve ailem en büyük şansım. Çünkü boşanma sürecinde beni hiç ylpratmadılar. Annem, babam ve kardeşlerim, bana neden bile sormadilar... sadece sen nasil mutlu olacaksan biz de öyle mutlu olacağız, biz arkandayız, ister evliliğe devam et, ister ayrıl, ama kararl sana bıraklyoruz, bizim bu konuda sana baskımı yok dediler; bu yüzden çok şansliyım...” (G21, 31 yaş).

Yukarıda da örneklendiği gibi, görüşülen akademisyen kadınların pek çoğunun boşanma sürecinde ailelerinin evliliğin sürdürülmesi yönünde baskıcı bir tavır sergilemediği, boşanmanın ardından yaşanan toparlanma sürecinde de hem maddi hem de manevi olarak destek verdikleri ortaya konulmuştur. Kadınlardan büyük çoğunluğu kendi kararlı duruşlarının ailelerinin desteğini almada etkili olduğunu ifade etmiştir. Bununla birlikte kadınlardan bazıları (2 kadın) kendi çekirdek ailelerinin değil ama bazı akrabalarının boşanmalarını hoş görmediklerini ve bu süreçte kendilerine hiç destek olmadıklarını belirtmişlerdir. Akraba çevresinin boşanma sürecinde deneyimlenen bu olumsuz müdahaleleri, boşanan kadınlara eşlerinin kusurlarını idare edemedikleri ve bir evliliği hoşgörüsüz ve itaatsiz tutumlarından dolayı yıkmaları nedeniyle yöneltilen suçlamalar şeklinde karşılık bulmuştur.

Ailelerin genel eğilimi, boşanma isteğinde olan çiftlerin özellikle çocuğu da kapsayan evliliklerini devam ettirmeleri yönündedir. Aile statüsünün azalmasından duyulan kaygı ailelerin boşanma karşıtı bir tutum sergilemelerine neden olur. Boşanmaya karşı direnç gösteren ve boşanmayı kadının bir başarısızlığı olarak gören bir toplumda, kızlarının boşanmaları nedeniyle statü kaybedeceğini düşünen aileler, toplumun geneli tarafından onaylanmayan bu durumu hoş karşılamazlar. Ne var ki çalışmamızın saha kısmında topladığımız veriler, boşanma sürecinde ailelerin kızlarına karşı çıkmadıkları gibi, çoğunlukla destek olduklarını ortaya çıkarmıştır.

\section{Dayanışma ve Sosyal İlişsiler}

Araştırmaya katılan boşanmış akademisyen kadınların boşanma sonrası sosyal çevrelerine ilişkin görüşleri iki kategori oluşturmuştur. Kadınların büyük bir çoğunluğu dayanışma içinde bulundukları insanlarla ilişkilerinde bir değişiklik olmadığını ve eski arkadaşlarıyla ilişkilerini devam ettirdiklerini belirtmişlerdir. Diğer grup görüşmeci ise boşanma sonrası sosyal ilişkilerinde bir kısıtlama olduğunu ifade etmiştir. Boşanma sonrasında eski çevreleriyle olan ilişkilerini sürdürmeye devam ettiklerini belirten kadınların hem boşanma sürecinde hem de sonrasında çevreleri tarafından hoşgörü ile karşılanıp desteklendikleri belirlenmiştir. Akademisyen kadınların boşanmanın olağan karşılandığı bir sosyal çevreye sahip olması da söz konusu desteği daha fazla hissetmelerinde etkili olmaktadır. Bu gruptaki kadınlardan evlilikleri süresince evi ihmal eden, kıskanç ya da evcimen karakteri dolayısıyla daha çok ev içinde ve insanlardan kopuk olarak yaşayan bir eşe sahip olan bazılarının boşanmalarıyla birlikte arkadaş çevrelerinin arttığını belirlenmiştir.

Çalışmanın saha kısmına ilişkin bu veriler, boşanmaya ilişkin Bohannon’un (1970) boşanma 
sürecinin toplumsal kabulünü içeren sosyal boşanma aşamasında çiftlerin boşanma sonrası yeni arkadaşlıklar edinebildikleri yönündeki görüşlerini desteklemektedir.

Boşanma sonrası sosyal çevrelerinin daraldığını da ifade eden kadınların hemen hepsi bu sınırlamayı kendilerinin getirdiğini, yalnızca bir kadın çok yakın bir arkadaşının boşandıktan sonra hiçbir gerekçe belirtmeksizin iletişimini kopardığını belirtmiştir. Diğer çalışmaların bulgularını destekler bir biçimde bu araştırmada da kadınların sosyal çevreleri ile iletişimlerini sınırlandırmalarındaki en önemli gerekçelerinin çiftlerle kurulan sosyal çevreye uyum sağlayamayacaklarını ya da boşanmaları nedeniyle kendi davranışlarının yargılanacağını düşünmeleri olduğu saptanmıştır.

“...benim sürekli görüştüğümüz ama şimdilerde hiç gitmediğim ama çok sevdiğim evli arkadaşlarım var; çünkü olmuyordu tek başınıza çocuklarınızı alıp gittiğiniz zaman bir akşam. Olmadı̆̆ını ben hissediyordum ve gitmemeye başladım, onlar da niye gelmiyorsun demediler açıkçası...” (G16, 49 yaş, b).

“...eski çevrenize giremiyorsunuz, şey olarak değil fiziksel anlamda girememek değil, tabi ki giriyorsunuz ama temkinli mi diyeyim dışlanmış mı diyeyim tam o kelimeyi bulamiyorum şu anda, belki boşanmışların deneyimlediği ya da hissettiği bir şey olabilir bu. Ama hissediyorsunuz, karşınızdaki çevrenizdeki evli çiftlerle bir program yapamıyorsunuz, şu alyansin da nelere kadir olduğunu gördüm...” (G15, 51 yaş, b).

Çevreleriyle kurdukları ilişkiyi sınırlandırdıklarını ifade eden kadınlardan bazıları için, sosyal çevrelerine sınırlama getirmelerinin nedeni kıskançlıktır. Görüştükleri evli kadınların kendilerini eşlerinden kıskandıkları ya da kıskanabileceklerini hissetmeleri de kadınlara çiftlerle kurulan sosyal çevreye uyum sağlayamayacaklarını düşündüren şeylerden biridir.

“...benimle iletişimi kesen olmadl, ama ben kestim. Mesela bir kız arkadaşımın, çok yakın, evinde daha önce evliyken falan kaldı̆̆ım bir kız arkadaşımın bir başka boşanmış bir arkadaşımızdan bahsederken şöyle bir şey söylediğini yaşadım; dedi ki o kişiden bahsederken "ben O'nun dul olduğunu bildiğim halde evime O'nu kabul ettim” dedi bir başka kişiden bahsediyordu. O günden sonra ben O'nun evine hiç gitmedim ki eşi de benim üniversiteden okul arkadaşım, kendisi benim çok yakın kız arkadaşım; böyle bir eve bir daha hiç gitmedim...” (G7, 43 yaş).

“...olmadl hiç böyle bir şey olmadl ama benim hassasiyetimden, kadınlar kıskançtır, kıskanırlar yani. Ben bir şey olduğu için değil; ona meyil vermemek için. Böyle bir şeyde özellikle, tabi ki evli arkadaşlarım var ama onlarla çok az görüşmeye gayret ettim...” (G6, 49 yaş, a).

Kadınların görüştükleri çevrelerini kısıtlama nedenlerinden bir diğerinin boşanmayla sonuçlanan evliliklerindeki sorunlarının arkadaşlar arasında konuşulmasından kaçınmak olduğunun belirlenmesi de boşanma olgusuyla ilgili pek çok çalışmanın bulgularını desteklemektedir. Örneklem içinde yer alan kadınlardan bazılarının evliliklerindeki sorunlarının arkadaşlar arasında konuşulmasıyla ilgili olarak duydukları kaygı düzeylerinin oldukça yüksek olduğu belirlenmiştir. Öyle ki görüşülen kadınlardan bazıları (4 kadın) boşandıklarını yakın arkadaşları dışında kimseye söylemediklerini belirtmişlerdir. 
“...çok düzgün bir bölüm başkanı ile çalışıyordum, çok babacan bir insand, babacan erkek yani. Yaklaşımı çok güzel oldu. Tabi şu da tartışılır; böyle bir olaydan sonra çok babacan şekilde yorum yaptı, ama belki de yorum yapılmaması gerekiyordu; çünkü bu benim özel hayatım. Bilmiyorum çok emin değilim hani çünkü evlenirken ilanla evleniyoruz, boşanırken özel hayatımız. Fakat beni rahatsız eden kısımlar şuydu; kadın iş arkadaşlarım, ki evlilerdi o esnada, ve erkek bölüm başkanım biraz fazla bu benim boşanmışlı̆ım fazla sohbet konusu oldu diyebilirim....” (G20, 38 yaş, b).

“...insanların neden boşandınız sorusu sürekli gündeme geldiği için açıkçası bana sıkıntı yarattı çünkü kimseye neden açıklama gibi bir ihtiyaç duymak, daha doğrusu ihtiyaç duymuyordum ama her gelen soru da bir cevap istiyordu ve böylece gitgide çevremi küçültmeye başladım açıkçası. Çünkü bu soruların sorulması tedirginlik yaratıyordu. Bu tedirginliğin sebebini bilmiyorum ama herkes bir sebep arlyordu oysa o sebep bana göre ya da eşime göreydi, kimseyi ilgilendirmiyordu. Belki de toplumsal algı diyelim, bilmiyorum..." (G12,37 yaş, b).

Daha önceki çalışmalarla da ortaya konulduğu gibi bu araştırmada da boşanmış kadınlardan çocuk sahibi olanların boşanma sonrası sosyal çevrenin daralmasıyla ilgili olarak daha hassaslaşmış oldukları belirlenmiştir. Bunların yanı sıra boşanmanın ardından kadınların eski sosyal çevrelerinin olduğu evlerinden taşınmaları, yeni bir işe başlama ya da iş yeri değiştirme zorunluluğu ve ekonomik kazanımın azalmasının da kadınların sosyal çevrelerinin sınırlanmasında etkili olduğu saptanmıştır.

Görüşülen kadınların büyük çoğunluğu (12 kadın) boşanma sonrasında sosyal ilişkilerinde bir değişiklik olmadığını, yarıya yakını (9 kadın) boşanma sonrasında davranışlarında son derece ölçülü olmaya çalıştıklarını belirtmişlerdir. Çalışmada görüşülen akademisyen kadınların pek çoğu da toplumun diğer kesimlerindeki kadınlar gibi negatif tutumlarla karşı karşıya kaldıklarını ve bununla mücadele etmek için çeşitli stratejiler geliştirdiklerini vurgulamışlardır.

“...tabi ki evli arkadaşlarım var ama onlarla çok az görüşmeye gayret ettim. Genellikle arkadaşlarım ya hiç evlenmemiş bayanlar ya dul bayanlar, onu da ifade edeyim ya da yalnız kişiler...” (G6,49 yaş, a).

“...Bu sefer daha klsitl bir çevreyle ve bekar olanlarla ya da evlenip ayrılmış olanlarla, şimdi bekar diyoruz tabi ama, evlenip ayrılmış olanlarla program yapmaya yıllardır çalışlyorum. Ki ne kadar tahsilli bir çevre olursa olsun, ne kadar üst düzeyde olursanı olun, ögretim üyesi de olsaniz maalesef bu geçerli. Eşsiz bir şekilde bir yere maalesef gidemiyorsunuz. Çok nadir, çok büyük bir şey olacak okulun bir gecesi olacak üniversitenin ya da bölümün siz ona ancak gidebilirsiniz, o düzeyde. Onun dişında daha biraz daha özel, daha küçük bir organizasyonda şey yapamazsiniz, yer alamazsınız. Bu kendi kendime koyduğum bir engelden ziyade, belki böyle olabilir ben bunu da kabul ediyorum, fakat etrafin hissettirdiği şey de o. Yani öyle bir engel de var...” (G15, 51 yaş, b). 
“...yani benim evliykenki giydiğim kiyafetleri daha sonra uzun bir süre giyemedim ben mini etek falan. Yani evli iken çok rahatlıkla yaptı̆̆ım birtakım şeyleri, çok uzun bir süre yapmadım. Şimdi yeni yeni yaptığım zaman da işte o dedikoduları duymaya başladım gerçekten de. Yani bunlar tabii ki kötü bir şey ama ne yazık ki o zaman onu yapma nedenlerinizin haklı olduğunu gösteriyor...” (G7,43 yaş).

Yukarıdaki örneklerde de görüldüğü gibi boşanma sonrasında davranışlarında ölçülü olmaya çalışmak, kadın erkek karışık toplantı ya da yemeklerde bulunmamak, giyim kuşamlarına dikkat etmek, eve geç saatlerde gelmemeye çalışmak, kendileri gibi boşanmış, bekar ve özellikle de kadınlardan oluşan arkadaş grupları oluşturmak bu stratejilerden bazılarıdır.

\section{Kendini Konumlandırma}

Örneklem içinde yer alan kadınların boşanma deneyimlerinin kendilerini konumlandırma biçimlerinde ne derece etkili olduğunu belirlemek için, kadınlara boşandıktan sonra kendilerini nasıl hissettikleri sorusu yöneltilmiş ve kadınların çok büyük bir çoğunluğunun (18 kadın) kendilerini rahatlamış ve huzurlu olarak nitelendirdiği belirlenmiştir. Bu rahatlama hissi bazı kadınlarca boşanmanın hemen ardındaki süreçte yaşanırken bazıları için ise ilk etapta yaşanan derin bir depresyon sürecini takiben ortaya çıkmıştır.

Boşandıktan sonraki süreçte kendilerini ilk başlarda kötü hisseden ve boşanmayı bir travma olarak nitelendiren kadınlardan 5'i çocuk sahibidir. Temel kaygıları çocuklarını tek başına yetiştirmek olan bekar annelerin boşanma sonrası stres düzeylerinin daha yüksek olduğu belirlenmiştir. Toplumun tek başına çocuk yetiştiren bir kadına olumlu bakmayacağı yönündeki inançlarının bu kadınların duydukları stres düzeyini daha da artırmış olduğu saptanmıştır.

“...yani bir kere rahatladım, üzerimden bir yük kalktı ama tabi ki endişe duymaya başladım; çünkü toplumda tek başına çocuk büyüten bir kadın olmak, toplumun bakış açısl, hani daha sonra ne olacak... Ve şey yapmak istemedim; hemen herkese ben boşandim diye ilan etmedim ama saklamadım da....” (G3, 44 yaş).

Çocuklarının bu süreçten olumsuz etkilenmeleri kaygısı, boşanmayı kabullenme sürecinde yaşanan zorlukların yanı sıra çocuklarıyla geçirdikleri zamanın azalması ya da onlardan ayrı kalmak boşanmış annelerden bazılarını depresyona sokan diğer kaynaklar olarak belirlenmiştir.

“...ilk zamanlar kötüydü. Yani uyandı̆̆ımda bunun hep böyle uyandı̆̆ımda rüya olmasını istedim çünkü çocuklarım yoktu. Ama yavaş yavaş alıştım yani bu duruma. Yani 2 senesi zaten hani çocukları kazanmaya yönelik geçti, küçüklerdi o zaman. Ama şu an geldiğim nokta, geç bile kalmışım boşanmakta gibi bir durumdayım yani...” (G18, 40 yaş, a).

“...bu arada kızım tabi babasıyla kalmıştl, onun sıkıntısı çok oldu, bir yıl da görüştürmedi babası. Dolayısıyla o klasik işte haberlerde duyduğunuz şeyleri yaşadım; tahsilliler yaşıyorlar mı yaşıyorlar böyle şeyleri, sadece çok gün ışı̆̆ııa çıkmıyor...” (G15, 51 yaş, b).

“...daha çok kızımın uyum süreci diyeyim. O’na çünkü boşanma fikrini çok geç kabul ettirebildim mi diyeyim ya da kabul etti mi diyeyim. Çünkü tam ergenliğe girdi o süreçte. Babası tekrar Türkiye'ye döndüğ̈ünde 
bizim evli olduğumuz düşüncesini yaşamaya başlad, bir aile olma düşüncesini. Mesela kardeş istedi, babam geldi artık bir kardeşim olmalı anne düşüncesi, en çok zorlandığım buydu...” (G12, 37 yaş, b).

Boşandıktan sonra ilk başlarda kendilerini çok mutsuz hissettiklerini belirten kadınlardan bazıları içinse, beklentilerinin karşılanmamasının ve de emeklerinin karşılıksız kalmasının yaratmış olduğu kırgınlık, boşanmanın hemen ardından yaşanan süreçte depresyona yol açan bir diğer kaynak olarak belirlenmiştir.

“...bir süre depresyona girdim mesela. 2 sene depresyon, öfke kontrolü ile ilgili bir tedavi gördüm. Hazmedemiyorsunuz çünkü bazı şeyleri, o anlamda çok... bu bende öfke olarak çıtı. Mesela hayattan zevk almama değil de kızımı görmek istememe, onunla çok ilgilenememe, her şeye çok çabuk kızma...” (G11, 37 yaş, a)

“...ben özel olduğunu düşünüyordum ilişkimizin, diğerlerinden farklı olduğunu düşünüyordum, herhalde herkes böyle düşünüyordur. Böyle olmadı̆̆ını görmek, beni çok üzdü. Herhalde en çok bu, evet ya biz de basitmişiz, biz de herkes gibiymişiz demek. Yani, hayatla ilgili kaygılardan çok daha duygusal şeyler...” (G21, 31 yaş).

Görüşülen boşanmış akademisyen kadınların boşanmalarının hemen ardından kendilerini mutsuz hissetmelerine sebep olarak, depresyona girmelerinde etkili olan diğer kaynaklar; geleceklerinin ne olacağına dair belirsizlik ve hayatta kimsesiz kaldıklarına dair duydukları inanç olarak belirlenmiştir.

“...hayatta tek kaldiğımı falan düşündüm. Etrafimda ailem vardı, aile sahip çıkan bir aile hani kalkıp, sahip çıkan derken maddi manevi sahip çıkan bir aileydi, fakat gene de ben hani sudan çıkmış balık vardır ya o şeyde bu kadar yıl sonra hani nasıl... Hep planları tipik Türk kadını olarak eşle birlikte yapmışsınız, çocukla birlikte yapmışsınız ikisi de çıkınca hayatınızdan böyle bomboş zamanı olan, zamanını nasıl geçirecek, neyle dolduracak, hani mesleki anlamda demiyorum o zaten var çalışlyorsunuz da, bir sürü zamanı kendisine kalan ama bir o kadar da psikolojik olarak boşluk hisseden bir duruma düştüm, bir boşluğa düşmüştüm...” (G15, 51 yaş, b).

“...biraz sahipsiz hissettim yani aileyi sahipsiz hissettim; çünkü ailem de çok uzak olduğu için bir destek olan, sanki böyle başını yaslayacağın bir omuz veya çocuklarımla birlikte kendimizi güvencede hissedeceğimiz bir ortamda olmayı çok arzuladım. Bunu çocuklarıma yansıtmadım onlar bana çok güveniyorlar, çünkü ama ben kendim böyle bir dost ya da bir arkadaş hatta yani eşimi bile çok istedim yani keşke olsaydı diye, öyle bir destek istedim...” (G16,49 yaş, b).

Araştırmada elde edilen veriler, ASAGEM (2011, 87-89) tarafından yapılan çalışmanın boşanmış kadınların zaman içinde eşlerinden ayrı da bir hayatı sürdürebildikleri ve çocuklarıyla yepyeni kurdukları hayatta daha mutlu hissetmeleri sayesinde stres düzeylerinin azaldığ bulgusuyla paralellik göstermektedir. Nitekim boşandıktan sonraki dönemde çok kötü hissettiklerini belirten annelerden bazıları aşağıdaki ifadede de izlendiği üzere boşanmalarının 
üzerinden zaman geçtikçe daha rahatlamış olduklarını vurgulamışlardır.

“...önce, önce çok şey hissettim, kötü hissettim, acayip kötü hissettim böyle hala işte hareketlerimde, dışarıdaki davranışlarımda, yaşantımda hâlâ onun, böyle 14 senenin vermiş olduğu nasıl diyeyim o zincirler, kendi iradenle hareket edememe durumu vard. Fakat hiç unutmuyorum aradan 20 gün falan geçti. Ben bir gün şöyle kalktığımı hatırlyyorum; oh be dedim bu ne ya, yani ne kadar güzel bir hayat. Yani sabah kalkttğında sürekli aynı tantanayl yapan bir adam yok, adamin üzerindeki baskısı yok. Aynen öyle hissetmiştim ve inanılmaz mutlu hissetmiştim...” (G5, 34 yaş).

Boşanan 21 akademisyen kadınla yapılan derinlemesine görüşmenin ardından, boşanmanın kadınlar için sadece olumsuz etkileri olan bir süreci ifade etmeyip; aksine kadınların yeni bir bağımsızlık duygusu ve kendine güven deneyimlemelerinin aracı olabildiği sonucuna varılmıştır. Araştırmadan edinilen bulgular, Virginia ve California eyaletleri ile İsveç'te (Clarke-Stewart, \& Brentano, 2006, 91-92) yürütülen ve boşanan kadınların iki yıldan sonra çok yüksek oranda (\%72) ruhsal olarak iyileşme gösterdikleri gibi, yüksek yeterlilik, kendine güven, kendi kendine yetebilme, kendi görüntülerini geliştirme ve sosyal yetenek ile karakterize edilmiş gruplarda yer alma olasılıklarının daha yüksek olduğunu ortaya çıkaran araştırmaların bulgularıyla paralellik göstermektedir.

Boşanmanın ardından kadınların kendilerini iyi hissetmelerinde etkili olan esas kaynağın ise meslek sahibi olmaları olduğu belirlenmiştir. İyi bir meslek sahibi olmaları sayesinde boşanmış olmanın yarattığı ekonomik sıkıntıyı çalışmayan ya da geçici işlerde çalışan hemcinslerine oranla daha kısa süreli yaşayan kadınlar, statüsü yüksek bir mesleklerinin olması bakımından da boşanmanın ardından yaşanan toparlanma sürecinde yeni çevreler edinerek boşanma sürecini görece daha rahat atlatabilmektedirler. Akademisyen kadınlar, iş yaşamlarını kendilerini sadece maddi olarak tatmin eden bir mekanizma değil aynı zamanda topluma katkı, sosyal tatmin olarak da nitelendirmişlerdir.

“...mezunlar derneği, X mezunlar derneği başkanlyım zaten orda çok ahbabım var, yani gene kendi çevremde. Benim dostlarım eksilmedi zaten, hatta $\operatorname{arttı...”~(G9,~} 47$ yaş, a).

“...aslında hiçbir zaman, çok komik olacak, hiçbir zaman mesela pişman olmadım. Hiçbir şeyden endişelenmedim. Ondan sonra, iyi bir kariyer yaptım, ... müdürlüğü yaptım 17 yll. Ondan sonra, hep kendimi işe verdim, hiçbir endişem olmadl...” (G6, 49 yaş, a).

“...bence toparlanma sürecinde kadınların bir mesleğinin olması çok önemli. Ben eğer bir işim olmasaydı o süreçte çok boşlukta hissederdim herhalde. Boşanmanin ardindan işime tutundum, öyle atlatabildim. İs sahibi olmak önemli bir şey boşanma sürecinde. Devletin boşanma sürecindeki bireyler için politikalar yürütmesi gerektiğini düşünüyorum ben, özellikle de kadınlar için. Hani nasıl hamilelik izni var, boşanma izni de olmalı insanın o travma sürecini atlatabilmesi için. Üstelik eğitimi olmayan ya da iş sahibi olmayan kadınların daha çok korunması gerekiyor. Çeşitli meslek edindirme kursları, kadınlara yönelik kurslar yoluyla kadınların hem kendi hayatların idame ettirebilmeleri sağlanmalı hem de topluma kazandırlmalı kadınlar böylece. Iyi bir meslek 
sahibi olmak bu süreçte belki de en önemli şey...” (G8, 36 yaş).

Meslek sahibi olmak, kadınların boşanmanın ardından yaşanan süreçte kariyerlerine odaklanarak yaşadıkları sıkıntılı süreci unutmalarına yardımcı olduğu gibi, enerjilerini işe yoğunlaştırmaları, başarı oranlarını yükselterek tatmin sağlamaktadır. Bu bakımdan meslek sahibi olmanın boşanma sürecinde ve boşanma sonrası yaşamda çok önemli bir belirteç olduğu söylenebilir. Akademisyen kadınların iş yaşamında yaşadıkları tatmin ve başarı hissi onların benlik saygılarını kazanmalarında etkili olurken, benlik algısı kadınların boşanma sonrasında en fazla güçlenme ve rahatlama hissettikleri alan olarak belirlenmiştir.

“...ben boşandiktan sonra çok değiştiğimi düşünüyorum. Beni hatta ögrencilerim bile görüyorlar, aa hocam siz misiniz tanıyamadık diyorlar. Ders anlatırken bile kendime güvenim geldi, bir duruşum değişti. Fiziksel anlamda da çok değiştim. Olumlu düşünüyorum, olumlu bakıyorum her şeye. Evet boşandım, olabilir. Boşanmayı da bu şekilde algillyorum...” (G2, 42 yaş).

“...boşandiktan sonra kendimi çok rahat hissettim. Çok kendime güvenim arttı, ayaklarımın üzerinde durabileceğimi anladım bir kez daha; çünkü bu evlilik süresince son 3 yıl o kadar yıpranmıştım ki kendime olan güvenimi yitirmiştim neredeyse. Çocuklarım bile bunu fark ediyordu. Okuldaki performansım da düşmüştü. Kendimi birazclk ezik hissediyordum açıkçası; ama boşandıktan sonra oh bunu başardım artık kendi başıma çocuklarımla birlikte devam edeceğim dedim ve aynı kararlılıkla da devam ediyorum...” (G16, 49 yaş, b).

Yukarıdaki örnek ifadelerin de ortaya koyduğu gibi, katılımcıların boşandıktan sonra deneyimledikleri en belirgin değişimlerden biri, güven duygusuna ilişkindir. Boşanmanın ardından yaşanan toparlanma sürecinde boşanmanın yarattı̆̆ tüm zorlukların üstesinden tek başlarına gelmeleri, yalnız ve başarılı olduklarını hissetmeleri ayrıca kadınların kendilerine güvenlerinin güçlenmesinde etkili olmuş, bu durum hayatları üzerinde daha fazla kontrol sahibi olmalarını sağlamıştır.

\section{Boşanma Algısı, Yeniden Evlenme ve Gelecek Konusundaki Düşünceleri}

Görüşülen kadınların hepsi, aynı koşullar altında bugün de boşanacaklarını belirtmişlerdir. Araştırmanın bu bulgusu, kadınların boşanma algılamalarıyla ilgili fikir vermektedir. Aşağıdaki örneklerde de izlendiği üzere, akademisyen kadınların büyük çoğunluğunun boşanma karşısında daha olumlu bir tavır aldıkları görülmüştür. Evliliklerinde psikolojik şiddetin varlı̆̆ını belirten akademisyen kadınların boşandıktan sonra özellikle vurguladıkları değişim, güven duygusuyla ilgilidir. Boşanmanın ardından yaşanan toparlanma sürecinde boşanmanın yarattığı tüm zorlukların üstesinden tek başlarına gelmeleri, yalnız ve başarılı olduklarını hissetmeleri de ayrıca kadınların kendilerine güvenlerinin güçlenmesinde etkili olmuştur.

“...ben var ya evli olduğumu falan hatırlamıyorum. Ya kesinlikle. İnanılmaz, hayatımın en doğru kararını almışım. Geç mi kalmışım, bilmiyorum hani zamanı demek ki oymuş. Beyin olarak olgunlaşmam gerekiyormuş bilmiyorum ben çok acayip mutluyum. Yani tabi ki sıkıntı yaşıyorum ama onsuzluğun verdiği huzur her şeye bedel...” (G5, 34 yaş). 
“...hemen boşanırdım, 3 yıl daha beklemezdim yani uzatmazdım. Şu anda çok daha rahatım, en azından kendime güvenim açısından. Çünkü evlilikte insanlar ne kadar okumuş bile olsalar erkek özellikle kadinı çok ezebiliyor yani dövmesine gerek yok laflarıyla, davranışlartyla, ilgisizliğiyle... O psikolojik durum çok kötü. O zaman da siz, inanın yürüyüşünüz değisisiyor. Öğrencilerinize ders anlatırken sanki ögrencileriniz hissediyor sizin kendinize olan güveninizin az olduğunu falan. O yüzden ben şimdiki aklım olsaydı daha erken boşanırdım ve daha çok maddi talepte bulunarak boşanırdım... Boşanmak gerçekten bir felaket değilmiş hatta ĕger çok kötü durumdaysanız yani manevi olarak yani baskı altındaysanız yapılması gereken en doğru şey olabilir. Bunu tabi ki çocuklara çok fazla yansıtmamak gerekiyor" (G16, 49 yaş, b).

“...dul kadın imgesiyle ilgili benim bir sorunum yok hani boşanmış olmak benim kişiliğimi kimliğimi azaltan, değersizleştiren bir durum olarak görmedim. Aksine o dönemde olaylarla başa çıkışım, bütün bu zorluklara göğüs gerişim, iş yerinde başa çıkışım nedeniyle kendime güvenimin de arttığını söyleyebilirim açıkçası...” (G14, 51 yaş, b).

Araştırmadan edinilen bu bulgular, Arıkan'ın $(1996,14)$ eğitimin geleneksel rol beklentilerinin değişmesinde etkin bir role sahip olduğu ve yüksek eğitim düzeyine sahip bireylerin boşanmaları günah ya da utanılacak bir durum olarak değerlendirmediklerinin belirlendiği çalışmasının bulgularıyla paralellik göstermektedir.

Kadınların boşanmalarına ilişkin gösterdikleri bu kararlılığın ve hatta evliliklerini daha önce sonlandırmak istemelerine yönelik katı tutum alışın nedeninin daha çok hayatlarını yeniden yorumlamalarıyla ilgili olduğu görülmüştür. Kadınların evlilikteki beklentilerinin karşılanmaması ve duygusal doyuma ulaşmamaları boşanma kararlarında etkili olmuştur. Geriye dönüp baktıklarında boşu boşuna sıkıntı çekmiş olduklarının farkına vardıklarını belirten kadınlar, bitirmiş oldukları evliliklerini zaman kaybı olarak değerlendirirken, çocuk sahibi olanlar ise tek kazanımlarının çocukları olduğunu söylemişlerdir. Kadınların hemen yarısı (9 kadın) çok daha önce boşanacaklarını belirtirken, buna gerekçe olarak da öyle olması halinde psikolojik ve fiziksel yıpranma düzeylerinin daha az olabileceğine yönelik inançlarını göstermişlerdir. Özellikle yaşları daha ilerlemiş olan kadınlar evliliklerini daha erken bitirmiş olsalardı yeni bir hayat için daha fazla umutları olabileceğini, her şeye yeniden başlamak için daha umut dolu ve güçlü olabileceklerini belirtirken; gelecekleri ve yeniden evlilikle ilgili kaygılarını da dile getirmişlerdir.

“...daha erken boşanırdım. Hiç bu kadar uzatmazdım. Yani gerek yokmuş. Çünkü elinizde bir şey kalmıyor çocuklar sade, 2 tane çocuk...” (G9, 47 yaş, a).

“...evet yine boşanırdım hem de bunu çok daha önce yapardım; çünkü gerçekten bu kadar sıkıntıyı niye yaşamışım ki diye düşünüyorum...” (G2, 42 yaş).

“... o yüzden boşanmak bence kötü bir şey değil, hatta iyi bir şey bile olabilir ki benim için öyle oldu. Ama birazcık daha kendimi düşünsem belki bu süreci daha kolay atlatırdım ya da belki bu evlilik daha önce 
biterdi, daha çabuk yolumuza bakardlk...” (G21, 31 yaş).

Boşanmış kadınların geleceğe yönelik planları irdelendiğinde, kadınların yarıdan fazlası (13 kadın) uygun birisi olduğu takdirde yeniden evlenmeyi düşündügünü belirtmiştir. Yeniden evlenmeyi düşünen kadınlardan yarısı yeniden evliliğe çok sıcak bakmadıklarını ifade etmekle birlikte, koşullarına uygun birini bulmaları halinde söz konusu kadınların yeniden evlenebilecekleri belirlenmiştir.

“...yeniden evliliğe çok sicak bakmıyorum... Daha doğrusu şöyle hani artık hiç kimsenin sorumluluğunu taşımak istemiyorum. Gerçekten iyiyse, iyi hiç uğraşmayacă̆ım hani evlenmek için de uğraşmam. Nasıl diyeyim ben o kadar çok özveride bulundum ki öbür evliliği yürütmek için de; nasıl olsa olur, insanlar iyi olursa olur, düzelir; artık böyle bir şeye inancım kalmadi. Olmayacaksa olmuyor, zaten bir şey çok iyi gidiyorsa olur; sorunlar baş gösteriyorsa, hani bir tırmanma varsa, kendini huzursuz hissediyorsan hiç uğraşmaya değmez diyorum. O anlamda çok beni sert bir insan yaptı diyebilirim ilişskilere karşı. Açı̆̆ım elbette, birine tabi ki aşık oluyorsunuz boşandıktan sonra, evlenmek isteyen birileri ile karşılaşlyorsunuz, ama eskisi kadar cesur olmuyorsunuz. Onun yerine diyorum kendi hayatımı kurarım isteyen dahil olur, ben istemediğimde de gider. Ama uyumlu birini bulursam çift olacağımı düşündüğüm herhalde evlenirim...” (G11, 37 yaş, a).

“...53 yaşındayım, bu yaşta tekrar evlenebileceğim birinin hayatıma gireceğini düşünmüyorum, sanmiyorum. Benim istediklerim olmaz, benim isteyebileceğim biri de beni istemeyebilir. Yani öyle birini bulabileceğimi sanmiyorum o yüzden de yeniden evlenebileceğimi düşünmüyorum. Ama olursa bana yakın, her şeyimi paylaşabileceğim biri, bu konuda da çok katı değilim, evlenmem demiyorum...” (G4, 53 yaş).

“...yani ben dediğim gibi ataerkil bir aileden geldiğim için düzgün bir insan olursa yeniden evlenmeyi düşünüyorum ama evlenmeyi yani eğlenmeyi değil. Bu devirde terimler çok birbirine girmiş durumda. Çok bu konuda samimi olduğuna inanmiyorum insanların o yüzden uzak kalyyorum. Yani evle iş arasında küçük bir dünyada yaşıyorum ama kismet yani gerçekten inanırsam. Güven sorunu yaşlyorum ve gerçekten inanırsam belki ama çok yüksek bir yüzde, ihtimal görmüyorum olursa klsmet diyeceğim sadece...” (G18, 40 yaş, a).

Yukarıdaki örnek ifadelerde de izlendiği gibi, yeniden evlenmeye daha olumlu bakan akademisyen kadınlardan bazıları için, evliliklerinde yaşadıkları problemleri tekrar yaşayabilme endişesi yeniden evlenmeleri için engel oluştururken, bazı kadınlar güvensizlik yaşadıkları için evlilikten çekinmektedir. Özellikle geç yaşlarındaki kadınlar ise daha çok yaşlarının yüksekliği ve yaşlarıyla bağlantılı olarak hem istedikleri kriterlerde hem de bekar bir erkekle karşılaşma ihtimallerinin düşüklüğünün yeniden evlenebilmeleri önünde bir engel olduğunu vurgulamışlardır.

“...hayat tek başına yaşanmıyor, tek başına hiçbir şey bir şey ifade etmiyor. Eve geldiğinde tek başına olmak güzel bir şey değil. Bunu bir ev arkadaşı ile gidebilirsin denilebilir ama onun açtı̆̆ boşluk başka bir şey. 
Hani bunu yaşayıp, bu hayalleri kurup, herkesin böyle bir hayali vardır ya; evleneceğim, bir çocuğum olacak, evim olacak, mutlu mesut işte pembe panjurlu yuvamız falan, hani biz böyle belki de böyle büyütüldüğüm için ben onu bir yoksunluk olarak görüyorum. Tek başıma yemek yemekten dahi hoşlanmiyorum. Evet böyle paylaşabileceğim bir şeyleri, konuşabileceğim, oturup anlaşabileceğim, bir şeylerimi anlatabileceğim, onu anlayabileceğim bir eş tabi ki istiyorum ve eş yani hani bu eş, ev arkadaşı eş olmuyor. Ben bir eşim olsun isterim hayatımda, ama nasıl olur onu bilemiyorum tabi ki, ama evlenmek istiyorum...” (G17, 32 yaş).

“...yeniden evlilik bana çok yakın durmuyor, yeniden evlenmeyi düşünmüyorum. Hayatımda şu an öyle biri yok, bu konuda çok katı değilim ama eski evliliğimde eksik olan şeyleri birinde bulduğum zaman evet o zaman evlenebilirim ama birlikte yürüyebileceğim, bir şeyleri hayatı paylaşabileceğim, dost olabileceğim, arkadaşım olan biri olursa evet onunla belki yeniden evlenebilirim..." (G10, 47 yaş, b).

Yukarıda da örneklendiği gibi, kadınlara yeniden evlenmeyi düşündüren nedenlerden en etkili olanının, paylaşım ihtiyacı ve yalnız kalma korkusu olduğu belirlenmiştir.

Yeniden evliliğe sıcak bakan boşanan kadınların bazıları (2 kadın) daha önceki evliliklerinde çocuk sahibi olmayan kadınlardan oluşmaktadır. Bu bağlamda yeniden evlenip çocuk sahibi olmak bu kadınları evliliğe motive ediyor görünmektedir.

“...yani evet evlenmek istiyorum, çünkü bir çocuğum olsun istiyorum ama iyi bir şekilde, iyi temeller üzerine kurulsun istiyorum böyle. $\mathrm{O}$ da zor bunu da biliyorum, ama kesinlikle kapılarımı kapattım, artık kesinlikle evlenmem gibi bir tavrım yok. Çünkü bir çocuğum olsun çok istiyorum...” (G17, 32 yaş).

Yeniden evlenmeyi düşünmediklerini belirten kadınların ( 8 kadın) evliliğe sıcak bakmamalarına gösterdikleri gerekçelerden en sık olarak karşılaşılanı, benzer olumsuzlukları yeniden yaşamaktan kaçınmak olmuştur. Kadınlar ayrıca tek başlarına ya da çocuklarıyla birlikte yaşadıkları hayatlarında çok huzurlu ve rahat olduklarını belirtmişler ve bu rahatlıklarının evlendikleri takdirde bozulabileceğine duydukları inanç da onların yeniden evlenmeyi düşünmemelerinde etkili olmuştur.

“...erkek diye bir şey istemiyorum ama manen istiyor musun; e istiyorum aslinda ama adam gibi adam yok, yok bilmiyorsun... Ya ben evliliği düşünmüyorum, çok gözüm kararmış ve korkmuş olarak ama manen dersen düşünüyor insan. Ama O kişi yok, öyle bir model yok dünyada veyahut da yok.... ama şimdi asla böyle bir şeye tahammülüm yok, yani çekemem. Böyle bir modeli görürsem direkt vururum yani, hiç. Onun için çok tabi çok sılkıntı çektiğim için kısacası hiç düşünmüyorum, E'yi, bile duymak istemiyorum, yani erkeğin e'sini bile duymak istemiyorum..." (G13, 57 yaş).

“...evliliğe hiçbir şekilde iyi bakmiyorum. Yani şöyle bir şey var bazen kendi kendime düşünüyorum mesela şu anda mesela erkek arkadaşım var hani çok seviyorum, ama bir erkekle evlenmek düşüncesi kafamda aynı 
evin içerisinde olduğum anda eski eşimle olan şeyler aklıma geliyor ve resmen terapi gerektirecek kadar böyle bir sikıntı baslyor üzerime. Yani herhalde muhtemelen öncesinde bir terapi almam gerekir. Hiçbir şekilde evlenmek istemiyorum mesela, hiçbir şekilde...” (G5, 34 yaş).

Boşanma deneyimine sahip bazı akademisyen kadınların ifadeleriyle de örneklendiği gibi, görüşülen akademisyen kadınlardan bazıları, yeniden evlendikleri takdirde benzer olumsuzlukları yaşayacaklarına inanma eğilimi göstermekte ve bu durum evliliğe uzak durmalarında etkili olmaktadır. Kimse karışmadan kararlarını tek başlarına alan, özgürce seçimler yapan ve hayatlarını kendi hür seçimleri doğrultusunda yönlendiren ve bu bakımdan da kendilerini rahat ve huzurlu olarak değerlendiren bazı akademisyen kadınların ise yeniden evlenmeleriyle birlikte bu rahat ve huzurlu hayatlarının bozulacağına dair inançları, yeniden evlilik karşıtı katı bir tutum almalarına sebep olmuştur.

Yeni bir evliliği düşünmeyen akademisyen kadınların gösterdikleri diğer önemli gerekçe ise, güven kaybı olarak belirlenmiştir. Yaşadıkları sorunlu evliliklerinden edindikleri kötü tecrübelerin evlilik kurumuna olan inançlarını sarstığını belirten bazı kadınlar (2 kadın) bu kötü deneyimlerinin çok büyük bir güven kaybına yol açtığını da vurgulamışlardır. Güven kaybı boşanmış kadınlarla yapılan bu araştırmanın en sık karşılaşılan bulgularından biri olmasına karşın sadece 2 kadın yeniden evlenme konusunda tek engel olarak güven kaybını vurgulamıştır.

“...güven problemim var herkese karşı. Ve çok güvensiz yaklaştığım için karşımdaki insana, bunu da hissettiriyor olmalıyım ki böyle bir şey tutturamıyorum, yeni bir düzen derler ya o düzen tutmuyor. Biçimsel olarak baktlğında her şeyin tamam olduğu bir şey yaşıyorum şu anda; hani evim, işim her şeyim tamam güzel ama koca bir boşluk var ve bu boşluk kolay da kapanır mı bilemiyorum. Çünkü çok kısa bir zaman da değil aslında. Çünkü 2,5 yılı geçmiş artık ben boşanalı ve artık bu halletmem gereken bir şey. Ama dönüp dönüp başa sardığımı fark ediyorum. Çünkü bir başkasını hani diyorum ki yine aynı şeyler, yine üzüntüler, böyle şeyler mi yaşayacağım diye böyle bir tedirginlik yaşıyorum bununla ilgili...” (G17, 32 yaş).

Çocuk sahibi olmak boşanmış kadınları yeniden evliliğe motive ettiği gibi kadınların boşanma karşıtı tutumlar sergilemelerinde de etkili olabilmektedir. Boşanmış akademisyen annelerden 1'i kız çocuk annesi olmasının yeniden evlilik düşüncesine sıcak bakmasına engel olduğunu aşağıdaki şekilde ifade etmiştir;

“...biraz da çocuk olması beni engelliyor; size iyi bir eşten sonra, iyi bir çocuğuna babalık yapacak mı? Tabi benim kızım var, cinsiyet erkek olması önemli; çok güvenmeniz gerekiyor, çok iyi tanımanız gerekiyor. $O$ yüzden de böyle bir şey planlamak çok zor. Ama dediğim gibi evliliğe çok sıcak bakmıyorum...” (G11, 37 yaş, a).

Örneklem içinde yer alan kadınların yeniden evlenmeyi düşünmemelerinde etkili olan faktörlerden bir diğeri, kadınların yeniden bir evlilik yapmak için gerekçelerinin bulunmaması olarak belirlenmiştir.

“...ben, evlilik fobim yok gerekirse evlenirim, ama şu anda evlenmek için bir sebebim yok ki, yani niye evleneyim. Şimdi düşünün insan niye evlenir; çocuk yapmak gibi bir derdim yok. Mesela baklyorum 30, 35 yaş 
civarındaki kadınlar biraz panikliyorlar, eyvah hani geç kalıyorum çocuk yapmam lazım. Ama benim yaşıma geldiğiniz zaman, ben 47 yaşımdayım, ben şimdi niye evleneyim. Yani benim bir beklentim yok, bir adamin kariyerinden sebeplenecek halim yok, zaten olabilecek en iyi yerdeyim. Parasal olarak bir sorunum yok, ay bu herifi kullanayım zenginmiş bak emekli maaşı bana kalır böyle bir hesabım yok. Kadro bulmak için, bilmem ne için yapacak halim yok. Yani aslında yükseldikçe yuva kurma bahanen azaldiğı için daha yalnız kallyorsun herhalde, ama yalnızlık da koymuyor aynı düzeyde yani çünkü ihtiyacın yok ki. Bu bir algı meselesi; bir erkek yok hayatımda aman olmazsa olmasın, ne olacak ki yani çok büyük bir eksiklik değil...” (G9, 47 yaş, a).

Kadınların yeniden evlenme düşüncesini etkileyen faktörlerden birinin yaş olduğu saptanmıştır. Görüşülen kadınlardan 32-40 yaş aralığında olanlar tekrar evliliğe daha sıcak baktıklarını belirtirken, evlenme gerekçeleri olarak da tek kalmak istememe, aile olmak ve çocuk sahibi olmak istemeyi göstermişlerdir. Yaş, kadınların yeni bir ilişki kurmaları sürecinde de belirleyici olmaktadır. Yeniden evlilik karşıtı bir tutum sergileyen genç yaşlarındaki akademisyen kadınlardan bazıları (5 kadın) bir ilişki yaşama fikrine daha açık olduklarını, bununla birlikte evliliği düşünmediklerini dile getirmişlerdir.

“...yeniden evliliğe sıcak bakmıyorum. Yani bir insan boşandıktan sonra neden ikinci kez evlenir ki. Hani çok kesin yargıda bulunmak istemem ama neden ikinci kez evlenirsiniz ki. İlişki yaşayabilirim, arkadaşlarım olabilir, ama bir daha evleneceğimi düşünmüyorum. Şu an çok huzurluyum, rahatım bunu da açıkçası bozmak istemiyorum...” (G1, 38 yaş, a).

44 ve 53 yaşları arasında olan 7 kadın ise kendi denklerini bulmak konusunda daha sıkıntı duyduklarını, bunun da yeniden evlenme olasılıklarını düşürdüklerini ifade etmişlerdir.

“...diğer bir çekince de, aslında benim çekincem değil, ama erkekler çekiniyorlar ve korkuyorlar çok kariyerli kadından. Korkuyorlar ve size yaklaşabilecek olan erkek sayısı otomatikman azaliyor zaten. Başka şey, biraz daha sert oluyorsunuz bir başka çekince ise. Siz daha sert olduğunuz için daha ulaşılamaz oluyorsunuz ve o ulaşılamazliğı gördüğü için yaklaşamıyorlar, böyle bir durumlar söz konusu ama düşünüyorum hayat arkadaşı açısından. Ama bunu o kadar çok bir şey kriterler var ki o kriterleri karşllayacak olan beyefendiler zor. Çünkü artık duygusal faktörler yerine daha mantıksal, daha rasyonel faktörler, rasyonel davranıldiğ için rasyonel faktörler yerini aldığ için bu zor...” (G15, 51, b).

Aşağıdaki örnek ifadelerle de kıyaslanabildiği gibi, boşandıktan sonra geçen zamanın da ayrıca yeniden evlenme düşüncesi üzerinde etkili olduğu belirlenmiştir. Özellikle yeni olan boşanmalarda (1-2 yıl) görüşülen kadınlar yeniden evlilik karşıtı katı bir tutum sergilerken; boşanmanın üzerinden zaman geçtikçe evlilik düşüncesine daha sık rastlanmıştır.

“...yeniden evliliği yıllar önce hiç düşünmedim yani son 2-3 yıldır düşünüyorum ama çok zor... Evet bir hayat arkadaşı gerekiyor artık bu yaştan sonra diyeyim, gençlerin tabi bilemiyorum söylemlerini ama, ifadelerini, bizim yaşımızdaki grup için söyleyebilirim bir hayat arkadaşı gerekiyor; çünkü çocuğunuz büyüyor, ailenin fertlerinin diğer planları, programları olduğu için siz bir hayat arkadaşı yalnız kalmamak adına 
istiyorsunuz fakat güvenebileceğiniz, kolay kolay güvenemiyorsunuz yaşadı̆̆ını deneyimlerden dolayı..." (G15, 51 yaş, b).

“... çok kötü baklyorum. Önceden ikinci kez, üçüncü kez evlenen insanları duyduğumda bu hiç tuhaf gelmezdi. "ne güzel, demek bir daha evlendi, aaa çocuğu olmuş, ne güzel işte şans yüzüne gülmüş" falan derdim. Şimdi bir insanın ikinci kere evleneceğini duyunca tüylerim diken diken oluyor. Bir insan diyorum nasll ikinci kez evlenebilir, hele üçüncü kez nasıl, nasıl cesaret edebilir böyle bir şeye, herhalde benim kadar acı çekmediler diyorum. Çünkü bana göre benim kadar acı çeken biri bir daha evlenmeye cesaret edemez. Şu an böyle düşünüyorum, boşanall yedi ay oldu, belki de herşey çok yeni olduğu için. Benim için çok uzak...” (G21, 31 yaş).

Araştırmanın bu verileri Yılmaz \& Fidan (2006, 56) tarafından yapılan ve boşanmayı deneyimleyen kadınların çoğunlukla olumlu duygular yansıttıkları, özellikle eğitim düzeyi yüksek olan, statü sunan bir işe sahip ve çevresinden sosyal destek alan kadınların boşanma sonrası yaşam kurmada ve sürdürmede daha istekli ve başarılı olduklarının bulgulandığı araştırmanın sonucuyla benzerlik göstermektedir.

Boşanmalar, sosyolojik, psiko-sosyal, ekonomik ve hukuksal boyutlarda yaşanan birbirleriyle bağlantılı birçok faktörün bir sonucu olarak ortaya çıkmaktadırlar. Boşanma oranlarında tırmanışa sebep olan bu etmenler, boşanan kadınların boşanma sonrası yaşamlarını da şekillendirmektedir.

\section{Sonuç}

Toplumsal yapıda etkili ve egemen olan ilkelerin değişmesiyle birlikte ekonomik, dini, siyasi ve ahlaki alanlarda görülebilecek değişimler, aile kurumunun da yeniden şekillenmesine yol açmaktadır. Toplumsal değişim, ailede değişimlere neden olurken bu değişimlerle bağlantılı olarak ailenin temelini oluşturan evlilik kurumu ve evliliğe yönelik beklentilerin de farklılaşmasına yol açmıştır. Evlilik sürecinde eşler arasındaki iletişim ve etkileşim alanları sınırlandığında ve evlilikten beklentiler, ailenin görev ve sorumlulukları ile örtüşmediğinde eşler, tercihlerini evlilik dışında kalacak şekilde kullanarak, evliliğe son vermektedirler.

Evliliğin boşanmayla sonuçlanmasında ise kadın, pek çok sorunla karşılaşmaktadır. Kadınların boşanma sonrası deneyimledikleri sorunların başlıcaları; ekonomik sıkıntılar, çocukların bakım ve eğitimleri, alışkanlıkların değişmesi ve bunların yanında yalnızlık ve psikolojik baskılardır. Yaş, evlilik süresi ve biçimi, doğum yeri gibi birtakım değişkenler ise kadınların gerek boşanma kararını verme gerekse de boşanma sonrası geleceklerini belirleme konusundaki tutumlarını farklılaştırmaktadır.

Araştırmaya katılan akademisyen kadınların büyük çoğunluğu, evliliklerini 20-25 yaşları arasında gerçekleştirmiştir. Görüşülen kadınların boşandıkları eşlerinin ilk evlenme yaşları kadınlara kıyasla daha yüksek olup, çoğunlukla 26-30 yaşları arasında toplanmaktadır. Hem boşanmış akademisyen kadınların hem de boşanmış oldukları eşlerinin ilk evlenme yaşları Türkiye ortalamasının üstündedir. Türk toplumunda evli erkeğin eşinden daha büyük olduğu yönündeki genel uygulamaya paralel bir biçimde boşanan kadınların çoğunluğunun (16 kadın) yaşı boşandıkları eşlerinden (0-7 yaş arasında) daha küçüktür.

Araştırmanın örneklemini oluşturan akademisyen kadınların eşlerinin öğrenim durumları 
lisans ve lisansüstünde yoğunlaşmakta ve eşleri ile benzerlik göstermektedir. Hem boşanmış akademisyen kadınlar hem de eski eşleri Türkiye geneline oranla daha yüksek bir eğitim seviyesine sahiptir. Görüşülen kadın akademisyenlerin boşanmış oldukları eşleri eğitim durumlarıyla yakından ilgili olarak serbest meslek, akademisyenlik, öğretmenlik, memuriyet ve de subaylık gibi belli bir gelir getiren ve statüsü olan işlerle meşguldür.

Boşanmış kadınlardan çocuk sahibi olanların (15 kadın) hemen hepsi (11 kadın) tek çocuk sahibi, diğerleri ise iki çocuk annesidir. Boşanma sonrası çocukların velayeti ve dolayısıyla bakımı, büyük bir çoğunlulukla kadınlardadır (13 kadın).

Boşanmış akademisyen kadınların hemen hepsinin sevgi ve arkadaşlık temeline dayalı, flört yolunu tercih ederek evlilikler gerçekleştirdiği saptanmıştır. Görücü usulü gerçekleştirilen evliliklerin sayısı ise çok düşüktür (2 kadın). Görüşülen akademisyen kadınların evlendikleri kişileri eş olarak seçmelerinde kurulan duygusal bağlar önemli bir belirteçtir. Duygusal bağların yanı sıra eşlerinde görüp etkilendikleri karakter özellikleri, fiziksel görünüm, sosyal benzerlikler de eş seçiminde önemli etkenlerdir. Toplum ve ailelerin beklentisi de akademisyen kadınların evlilik kararı vermelerinde etkili olmuştur. Ne var ki evlilik sürecinde yaygın bir tanışma aracı olduğu belirlenen flört sayesinde evlilik öncesinde eşler birbirlerini tanıyıp arkadaşlık etmelerine rağmen evlilik birlikteliklerini sürdürememişlerdir.

$\mathrm{Bu}$ çalışmada, evliliğin boşanmayla sonuçlanmasında etkili olan faktörlerden birisinin eşler arası iletişimsizlik olduğu saptanmıştır. Daha çok eşlerin bakış açılarının farklılığından kaynaklanan iletişim kopukluğunu tetikleyen faktörlerin başında ise eşlerin birbirlerini ve ev içindeki rollerini ihmal etmeleri gelmektedir. Araştırma kapsamındaki çalışan kadınların eşlerinin kadının çalışma hayatı ile birlikte artan sorumluluklarını göz ardı ederek paylaşımdan uzak tutumlar sergilemeleri, evlilikte sorunlara neden olabilmektedir. Evlilikte gerginlik yaratarak, boşanmayı kadınların gündemine taşıyan önemli faktörlerden bir diğerinin, kadınların evlilikten beklentilerin karşılanmaması olduğu saptanmıştır.

Evlilikte yapılan borçlar, eşin işsiz olması ve ailesel sorumluluklarını yerine getirmeye isteksizliği gibi sorunlar da akademisyen kadınların boşanma kararlarında etkili olmuştur. Ancak ekonomik sorunlar, başlı başına bir boşanma nedeni olarak değil, bir tetikleyici olarak boşanma sürecini etkilemiştir.

Kadınlar genellikle bu sorunların çözümüne yönelik olarak eşleriyle iletişim kurmaya çalıştıklarını ve sorunların çözümüne yönelik tartışma isteğinde olduklarını ifade etmişlerdir. Kadınlar çözüm sürecinde aile büyüklerinden destek aldıklarını belirtmekle birlikte daha çok aile sorunlarıyla ilgilenen uzmanlardan yardım alma girişiminde bulunmuşlardır. Ancak bu gayretlerinin kişisel bir çaba olarak kaldığını ve sorunların çözümünde etkili olamadığını belirtmişlerdir. Sonuç olarak evlilik içindeki sorunların çözümsüz kaldığı görülmektedir. Çözümün üretilemediği buna karşılık çatışmaların giderek arttığı evliliklerin boşanmayla neticelendiği gözlenmektedir.

Örneklem içinde yer alan akademisyen kadınlardan bazıları için boşanma, ekonomik zorlukları, bazıları içinse sosyal ve psikolojik yıpranmayı beraberinde getirirken; bazı kadınlar için boşanma, evlilikte yaşanan sıkıntıların sona erdiği ve rahatlamanın yaşandığı bir süreci ifade eder. Eğitimli, çalışan ve şehirli kadının boşanması, kadının özgürleşmesinin bir göstergesi gibi algılansa da, geleneksel değerlerin tam olarak terk edilip modern tutumların benimsenmediği bir toplumda kadınların boşanmanın ardından ne kadar yüksek bir statüye sahip olsalar da, olumsuz yaklaşımlarla karşılaştıkları ve bunun da yaşamlarını etkilediği, pek çok açıdan hayatlarını sınırladığı belirlenmiştir. 
Görüşülen kadınların büyük çoğunluğu (12 kadın) boşanma sonrasında sosyal ilişkilerinde bir değişiklik olmadığını belirtmekle birlikte, boşanmış kadınların yarıya yakını (9 kadın) boşanma sonrasında davranışlarında son derece ölçülü olmaya çalıştıklarını belirterek, toplumsal yargılara dikkat çekmişlerdir. Türk toplumunda boşanma, evliliğin bireyler için çekilmez bir hale geldiği noktada bir çözüm yolu olarak görülmesine rağmen, gündelik hayatta pek hoş karşılanan bir durum değildir ve boşanmış bireylere karşı önyargılar artan boşanma oranlarına rağmen devam etmektedir. Özellikle boşanmış kadınlar toplum tarafından marjinalize edilme tehlikesiyle karşı karşıya kalırlar. Bu bakımdan çalışmamızda görüşülen akademisyen kadınların pek çoğunun da toplumun diğer kesimlerindeki kadınlar gibi karşı karşıya kaldıkları negatif tutumlarla mücadele etmek için çeşitli stratejiler geliştirdikleri saptanmıştır. Görüşme yapılan kadınlardan bazıları, kendi kimliklerinin ne kadar güçlü olduğunun bilincinde olduklarını ve bunun toplumun geleneksel yargılarıyla sarsılamayacağını belirtmiş, bu bakımdan da boşanmalarından ötürü kendilerine yönelik olumsuz tavırları önemsemediklerini ifade etmişlerdir. $\mathrm{Ne}$ var ki bu kadınlar ya da hiçbir negatif tutumla karşılaşmadıklarını ifade eden kadınlar dahi, görüşme esnasında topluma uyum sağlamaya çalıştıklarını vurgulamışlardır. Kadınların toplumun önyargılarını bertaraf etmek için uğraşmak yerine, topluma uyum sağlamak amacıyla stratejiler geliştirmeleri ise dikkat çekicidir.

Örneklem içinde yer alan kadınların hepsi, aynı koşullar altında bugün de boşanacaklarını belirtmişlerdir. Araştırmanın bu bulgusu, kadınların boşanma algılamalarıyla ilgili de bir fikir vermektedir. Yüksek eğitim düzeyine sahip akademisyen kadınların boşanmayı evliliğin tüm çabalara rağmen bir çıkmaza girdiği anlarda başvurulabilecek sağlklı bir son çare olarak değerlendirdikleri ve boşanma karşısında daha olumlu bir tutum sergiledikleri sonucuna varılabilir. 


\section{KAYNAKÇA}

Adak, N. (2007). “Toplumun Temel Yapı Taşı”. Ed. S. Güçlü. Kurumlara Sosyolojik Bakış, 49-91. İstanbul: Birey Yayıncılık.

Alptekin, K. (2011). "Düzce İl Merkezindeki Boşanmalar Üzerine Bir Çalışma”. Toplum ve Sosyal Hizmet, 22/2, 37-62.

Amato, P. R. (2000). “The Consequences of Divorce for Adults and Children”. Journal of Marriage and Family, 62/49, 1269-1287.

Amato, P. R., \& Previti, D. (2003). "People's Reasons for Divorcing: Gender, Social Class, the Life Course, and Adjustment”. Journal of Family Issues, 602-626.

Arıkan, Ç. (1996). Halkın Boşanmaya İlişkin Tutumları Araştırması. Ankara: T.C. Başbakanlık Aile Araştırma Kurumu Yayınları.

Arpacı, F., \& Tokyürek, S. (2012). "Boşanmış Bireylerin Yeniden Evlilik Konusundaki Görüşlerinin İncelenmesi”. Akademik Baklş Dergisi, 31, 1-15.

Aydın, O., \& Baran, G. (2010). “Toplumsal Değişme Sürecinde Evlenme ve Boşanma”. Toplum ve Sosyal Hizmet, 21/2, 117-126.

Battal, A. (2008). Boşanma Sebepleri Bilimsel Araştırma Projesi Uygulama Sonuçları. T.C. Başbakanlık Aile ve Sosyal Araştırmalar Genel Müdürlüğ̈̈. İstanbul: Eflatun Matbaacılık.

Beck, U., \& Beck-Gernsheim, E. (2012). Asskın Normal Kaosu. Ankara: Siyasal Kitabevi.

Bohannon, P. (1970). “The Six Stations of Divorce”. Ed. P. Bohannon. Divorce and After, 33-62. Garden City, New York: Doubleday and Company, Inc.

Boşanma Nedenleri Araştırması (2009). Ankara: T.C. Başbakanlık Aile ve Sosyal Araştırmalar Genel Müdürlüğü Yayınları.

Browne, K. (2005). An Introduction to Sociology. United Kingdom: Polity Press.

Canatan, K., \& Yıldırım, E. (2009). Aile Sosyolojisi. İstanbul: Açılım.

Clarke-Stewart, A., \& Brentano, C. (2006). Divorce: Causes and Consequences. New Haven and London: Yale University Press.

Coates, B. A. (2008). Divorce with Decency. United States of America: University of Havaii Press, Versa Press.

Demircioğlu, N. S. (2000). Boşanmanın, Çalışan Kadının Statüsü ve Cinsiyet Rolü Üzerine Etkisi. Yayınlanmış Doktora Tezi, Ege Üniversitesi, İzmir.

Fine, M. A., Ganong, L. H., \& Demo, D. H. (2005). "Divorce as a Family Stressor". Families \& Change, 227-252, University of Georgia, SAGE Publications.

Forste, R., \& Heaton, T.(2004). "The Divorce Generation:Well-Being, Family Attitudes, and Socioeconomic Consequences of Marital Disruption”. Journal of Divorce \& Remarriage, 41/1, 95- 114.

Giddens, A. (2005). Sosyoloji. Ankara: Ayraç.

İçli, T. G. (2007). Kriminoloji. Ankara: Seçkin

İlbars, Z. (2007). "Suç Antropolojisi: Kadın ve Suç”. Ankara Üniversitesi Dil ve Tarih Coğrafya Fakültesi Antropoloji Dergisi, 22, 1-13.

İmamoğlu, O. (1993). "Değişen Dünyada Değişen Aile İçi Roller”. Kadın Araştırmaları Dergisi, 1, 58-68.

Kandiyoti, D. (1984). “Aile Yapısında Değişme ve Süreklilik: Karşılaştırmalı Bir Yaklaşım”. Türkiye’de Ailenin Değişimi Toplumbilimsel İncelemeler. Ankara: Türk Sosyal Bilimler Derneği.

Kessler, S. (1975). The American Way of Divorce: Prescriptions for Change. Chicago: Nelson-Hall.

Koray, M. (1993). Çalışma Yaşamında Kadın Gerçekleri. İzmir: Basisen Eğitim ve Kültür Yayınları.

Minibaş, T. (1998). “Türkiye’nin Kalkınma Sürecinde Kadın İşgücü”. Ed. N. Arat. Aydınlanmanın Kadınları, 331-349. İstanbul: Cumhuriyet Kitapları.

Newman, D. M. (2009). Families: A Sociological Perspective. United States of America: McGraw-Hill Companies, Incorporated.

Özar, Ş., \& Yakut-Çakar, B. (2012). “Aile, Devlet ve Piyasa Kıskacında Boşanmış Kadınlar”. Kültür ve 
Siyasette Feminist Yaklaşımlar. 16. Kaynak: http://www.feministyaklasimlar.org/index.php?act=in Parrillo, V. N., Stimson, J., \& Stimson, A. (1995). Contemporary Social Problems. United States of America: Library of Congress, Cataloging-in- Publication Data. Boston: Allyn and Bacon.

Sayın, Ö. (1990). “Aile Sosyolojisi Ailenin Toplumdaki Yeri”. Bornova, İzmir: Ege Üniversitesi Edebiyat Fakültesi Yayınları, 57.

Sucu, İ. (2007). Boşanmış Kadınların Boşanma Nedenleri ve Boşanma Sonrası Toplumsal Kabulleri Sakarya İli Örneği. Yayınlanmış yüksek lisans tezi. Sakarya Üniversitesi, Sakarya.

Süleymanov, A. (2009). “Çağdaş Türk Toplumlarında Aile ve Evlilik İlişkileri”. Aile ve Toplum, 5/17, 7-17.

Tek Ebeveynli Aileler (2011). T. C. Aile ve Sosyal Politikalar Bakanlığı Ankara: T.C. Başbakanlık Aile ve Sosyal Araştırmalar Genel Müdürlüğü (ASAGEM) Yayınları.

Telsiz, M. (1995). “Evli Kadınların Evlilik Öncesi Evde İşbölümüyle İlgili Beklentileri ve Mevcut Uygulamanın Karşılaştırmalı Analizi”. Kadın Araştırmaları Dergisi, 3, 83-93.

Thompson, L., \& Walker, A. J. (1989). "Gender in Families: Women and Men in Marriage, Work, and Parenthood”. Journal of Marriage and Family, 51/4, 845-871.

Wiseman, R. S. (1975). “Crisis Theory and The Process of Divorce”. Social Casework, 56/4, 205-212.

Yılmaz, T., \& Fidan, F. (2006). "Kadın Açısından Boşanma: Yeni Bir Başlangıç Mı? Ya Da Son Mu?”. Tabuları Aşmak Temalı II. Uluslararası Kadın Araştırmaları Konferansı, Kıbrıs. 